\title{
Review \\ Current Options and Future Directions for NAFLD and NASH Treatment
}

\author{
Chunye Zhang ${ }^{1}$ and Ming Yang ${ }^{2, *}$ (i) \\ 1 Department of Veterinary Pathobiology, University of Missouri, Columbia, MO 65211, USA; \\ czvw9@mail.missouri.edu \\ 2 Department of Surgery, University of Missouri, Columbia, MO 65211, USA \\ * Correspondence: yangmin@health.missouri.edu
}

Citation: Zhang, C.; Yang, M. Current Options and Future Directions for NAFLD and NASH Treatment. Int. J. Mol. Sci. 2021, 22, 7571. https://doi.org/10.3390/ ijms22147571

Academic Editors: Giuseppe Colucci, Mariapia Vairetti and

Andrea Ferrigno

Received: 23 June 2021

Accepted: 13 July 2021

Published: 15 July 2021

Publisher's Note: MDPI stays neutral with regard to jurisdictional claims in published maps and institutional affiliations.

Copyright: (c) 2021 by the authors. Licensee MDPI, Basel, Switzerland. This article is an open access article distributed under the terms and conditions of the Creative Commons Attribution (CC BY) license (https:// creativecommons.org/licenses/by/ $4.0 /)$.

\begin{abstract}
Nonalcoholic fatty liver disease (NAFLD) is the most common chronic liver disease worldwide, with a broad spectrum ranging from simple steatosis to advanced stage of nonalcoholic steatohepatitis (NASH). Although there are many undergoing clinical trials for NAFLD treatment, there is no currently approved treatment. NAFLD accounts as a major causing factor for the development of hepatocellular carcinoma (HCC), and its incidence rises accompanying the prevalence of obesity and diabetes. Reprogramming of antidiabetic and anti-obesity medicine is a major treatment option for NAFLD and NASH. Liver inflammation and cellular death, with or without fibrosis account for the progression of NAFLD to NASH. Therefore, molecules and signaling pathways involved in hepatic inflammation, fibrosis, and cell death are critically important targets for the therapy of NAFLD and NASH. In addition, the avoidance of aberrant infiltration of inflammatory cytokines by treating with $C C R$ antagonists also provides a therapeutic option. Currently, there is an increasing number of pre-clinical and clinical trials undergoing to evaluate the effects of antidiabetic and anti-obesity drugs, antibiotics, pan-caspase inhibitors, CCR2/5 antagonists, and others on NAFLD, $\mathrm{NASH}$, and liver fibrosis. Non-invasive serum diagnostic markers are developed for fulfilling the need of diagnostic testing in a large amount of NAFLD cases. Overall, a better understanding of the underlying mechanism of the pathogenesis of NAFLD is helpful to choose an optimized treatment.
\end{abstract}

Keywords: nonalcoholic fatty liver disease; nonalcoholic steatohepatitis; molecules; signaling pathway; treatment options; clinical trials

\section{Introduction}

Nonalcoholic fatty liver disease (NAFLD) is the most common chronic liver disease worldwide, ranging from simple hepatic steatosis to advanced stage of nonalcoholic steatohepatitis (NASH), which may lead to liver fibrosis, cirrhosis, and hepatocellular carcinoma (HCC) [1]. Recently, a new definition was suggested for NAFLD, namely metabolic dysfunction-associated fatty liver disease (MAFLD) [2]. The prevalence of MAFLD among obese adults worldwide is $50.7 \%$, with $95 \%$ CI 46.9-54.4 [3], relatively higher in men (59.0\%, 95\% CI 52.0-65.6) than women (47.5\%, 95\% CI 40.7-54.5). NAFLD is tightly associated with obesity, diabetes, and metabolic syndromes [4,5]. A survey study showed that over the past three decades, NAFLD is the only consistently increasing liver disease in the United States, accompanying the increase in obesity and type 2 diabetes mellitus (T2DM) [5]. In addition to Western countries, the prevalence of NAFLD also increases in the past two decades in Asian countries, due to the sedentary lifestyle, overnutrition, obesity, and T2DM [6].

Both genetic and epigenetic factors impact the development and progression of NAFLD and NASH [7,8]. For example, the allele variant of rs738409 C > G in the patatin-like phospholipase domain containing 3 (PNPLA3) can increase the susceptibility of NAFLD and NASH, which was found from studies in Brazil $[9,10]$. In addition, NASH patients with PNPLA3 GG alleles had a higher level of aspartate aminotransferase (AST) and advanced liver fibrosis compared to patients with PNPLA3 CC alleles [10]. As the most evaluated 
epigenetic factor, DNA methylation in the $\mathrm{CpG}$ islands can be applied to test the progression of NAFLD to liver fibrosis and HCC [11,12]. These factors have been well described in other review papers $[13,14]$, which will not be discussed here.

In the past decade, non-invasive diagnostic techniques and novel therapeutic strategies have been developed. In this review, we first discuss the underlying molecular mechanisms of the pathogenesis of NAFLD and NASH. Then, we summarize the latest progression of diagnostic markers applied in NAFLD, NASH, or both. Following the investigation of the molecules in the pathogenesis and diagnosis of NAFLD and NASH, the potential therapeutic targets are summarized. Finally, treatment options in pre-clinical trials and clinical trials are discussed.

\section{Important Molecules and Their Mediated Signaling Pathways in NAFLD and NASH}

There are some essential molecules and their associated signaling pathways involved in the progression of NAFLD by mediating the lipid and sugar metabolism, cell apoptosis, liver inflammation and fibrosis, and so on. For example, the well-known transforming growth factor-beta 1 (TGF- $\beta 1$ ) signaling pathway plays critical roles in liver cell apoptosis [15], inflammation [16], NAFLD, and NAFLD-related HCC progression [17,18]. The signaling pathways involved by important molecules are potential targets for developing NAFLD and NASH diagnosis and treatment. Here, we summarize some latest findings in this field (Figure 1).

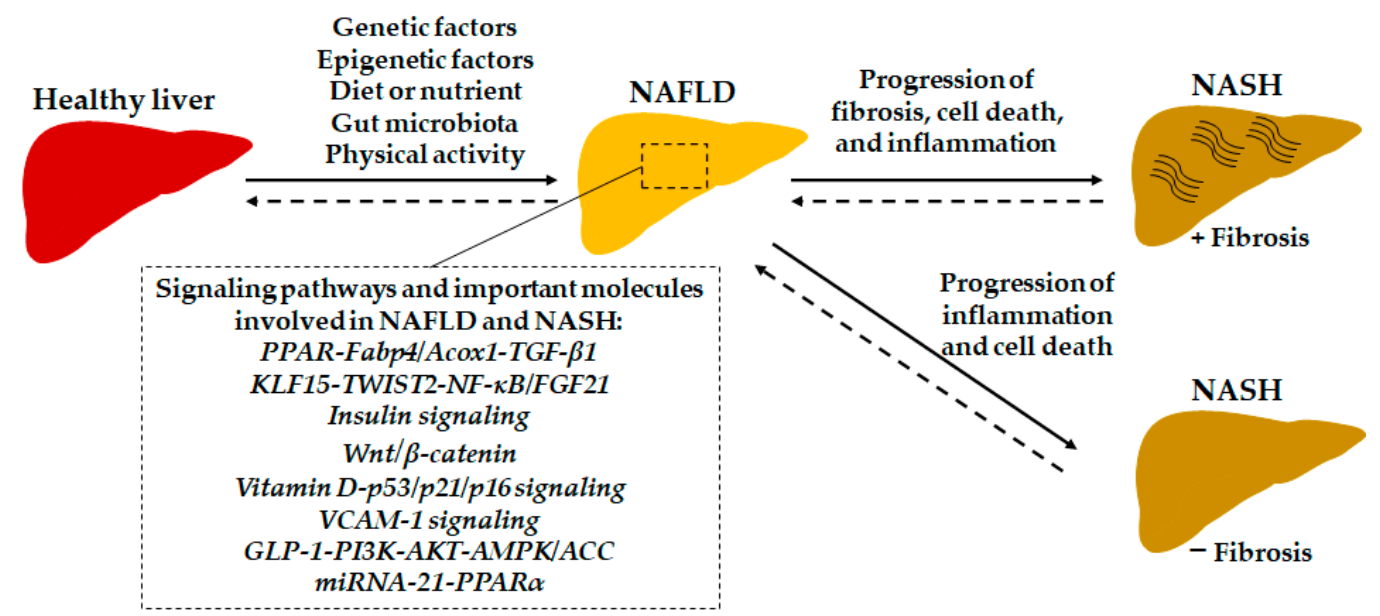

Figure 1. The important molecules and signaling pathways are involved in the development of NAFLD and the progression of NASH. Abbreviations: ACC, acetyl-CoA carboxylase; Acox1, acyl-CoA oxidase 1; AKT, protein kinase B; AMPK, AMP-activated protein kinase; Fabp4, fatty acid-binding protein 4; FGF21, fibroblast growth factor 21; KLF15, Krüppellike factors 15; GLP-1, glucagon-like peptide-1; NF- $k B$, nuclear factor (NF)-кB; PI3K, phosphoinositide 3-kinase; PPAR, peroxisome proliferator-activated receptor; TWIST2, twist-related protein 2; VCAM-1, vascular cell adhesion molecule 1.

\subsection{Peroxisome Proliferator-Activated Receptors}

The peroxisome proliferator-activated receptors (PPARs) are nuclear receptor proteins and play a vital role in modulating fatty acid and glucose metabolism. There are three subtypes of PPARs: PPAR $\alpha, P P A R \beta / \delta$, and PPAR $\gamma$. Currently, the single and dual PPAR agonists have been applied in the clinic for the treatment of hyperlipidemia, T2DM, metabolic syndrome and associated cardiovascular diseases [19]. For example, a PPAR $\gamma$ activator, rosiglitazone approved by the FDA for the treatment of T2DM, showed effects against steatosis, hepatocellular inflammation, ballooning degeneration, and fibrosis [20]. A clinical trial study showed that treatment with lobeglitazone, a dual PPAR $\alpha / \delta$ agonist, at a dose of $0.5 \mathrm{mg}$ daily for 24 weeks, significantly improved glycemic, hepatic steatosis, and serum enzymes for liver damage in T2DM patients with NAFLD [21]. Another antidiabetic drug elafibranor (GFT505), a dual PPAR $\alpha / \delta$ agonist, can improve NASH and 
multiple cardiometabolic risk factors associated with metabolic syndrome and T2DM without worsening fibrosis at a dose of $120 \mathrm{mg} / \mathrm{d}$ for one year [22]. Molecular mechanism study showed that elafibranor can promote lipid metabolism by upregulating genes such as fatty acid-binding protein 4 (Fabp4) and acyl-CoA oxidase 1 (Acox1), and inhibit liver inflammation and liver fibrosis, evidenced by inhibited expression of genes such as $C-C$ motif chemokine ligand 6 (CCL6), TGF- $\beta 1$, type one collagen alpha 1 (Col-1A1), and tissue inhibitor of metalloproteinases 1 (TIMP-1) [23].

\subsection{Krüppel-Like Factors}

Krüppel-like factors $(K L F s)$ are transcription factors that play pivotal roles in diseases. For example, KLF10-deficient mice on a high-sucrose diet promoted the progression of hepatic steatosis, inflammation, and fibrosis compared to wild-type mice [24]. Another study showed that KLF15 can activate twist-related protein 2 (TWIST2) to ameliorate liver steatosis and inflammation by modulating nuclear factor $(N F)-\kappa B$ or sterol regulatory element-binding protein 1c (SREBP1c)-fibroblast growth factor 21 (FGF21) signaling pathways [25]. Global knockdown of KLF6 or hepatocyte-specifical knockdown of KLF6 can improve glucose and lipid metabolism, as well as insulin tolerance by attenuating the function of PPAR $\alpha$ [26]. However, most of the current studies are pre-clinical investigations, and so the significant role of KLFs in human liver pathogenesis remains to be clarified.

\subsection{Insulin Signaling Pathway}

Insulin resistance (IR) is a feature of metabolic dysfunction, which contributes to the development of NAFLD and NASH. Hepatic insulin resistance can induce dyslipidemia and increase the development of atherosclerosis, as 100\% of hepatic insulin receptor knockout (LIRKO) mice developed hypercholesterolemia but not wild-type mice on an atherogenic diet for 12 weeks [27]. An increase in IR can impair glucose homeostasis in NAFLD patients [28]. Treatment of Eugenol, an aromatic oil extracted from cloves, activated insulin receptor substrate-2 (IRS-2) to improve IR evidenced by reducing Homeostasis model assessment for insulin resistance (HOMA-IR) and hepatic triglycerides [29]. Improving hepatic insulin sensitivity by treatment of insulin sensitizers can also improve glycemia or glycose tolerance and liver function [30]. Treatment with pioglitazone, an antidiabetic drug for T2DM, can enhance insulin signaling and increase glucose uptake and lipid metabolism in adipose tissue and reduce liver gluconeogenesis [31]. In addition, pioglitazone shows a therapeutic effect against NAFLD/NASH by reducing hepatic steatosis and anti-lobular inflammation via regulating PPAR $\gamma$ signaling and mitochondrial gene expression $[32,33]$.

\subsection{Wnt Signaling Pathway}

The Wnt family consists of 19 members in human. Among them, Wnt1, Wnt2, Wnt2b, Wnt3, Wnt3a, Wnt7a, Wnt8, Wnt8b, and Wnt10a are involved in the canonical Wnt signaling pathway, while Wnt4, Wnt5a, and Wnt11 are implicated in the noncanonical Wnt signaling pathway [34]. Activation of canonical $W n t / \beta$-catenin signaling pathway can enhance the development and progression of primary liver cancers [35,36]. Canonical Wht/ $\beta$-catenin and non-canonical Wnt signaling pathways are also implicated in the progression of NASH and liver fibrosis. For example, the expression of aortic carboxypeptidase-like protein $(A C L P)$, a secreted glycosylated protein in hepatic stellate cells (HSCs), is associated with mouse and human NASH by activating canonical $W n t / \beta$-catenin [37]. The expression of Wnt5a and Wnt11 was increased by 3 -fold and 15-fold, respectively, in the diet-induced mouse NASH model, indicating the involvement of non-canonical Wnt signaling in NASH progression [38].

\section{5. p53 Signaling Pathway}

Tumor suppressor gene $p 53$ plays an important role in the pathogenesis of NAFLD and NASH $[39,40]$. For example, silencing p53 in human liver cancer cell lines HepG2 cells and 
Huh7 cells decreased palmitate-induced lipid accumulation [41]. In addition, p53-deficient mice significantly reduced hepatic lipid accumulation and high-fat diet (HFD)-induced NAFLD symptoms in vivo. Supplementation of vitamin D can reduce the senescence and apoptosis of hepatocytes via inhibiting $p 53, p 21$, and $p 16$ signaling pathways, resulting in amelioration of NAFLD [42]. In contrast, long-term activation of $p 53$ with low-dose of doxorubicin showed a beneficial effect on the HFD-induced murine NAFLD model, including reduction of lipogenesis, inflammation, and endoplasmic reticulum (ER) stress [43], which was abrogated in liver-specific $p 53$ deficiency mice. Moreover, $p 53$ is also implicated in the pathogenesis of liver fibrosis [44,45] and HCC [46,47].

\subsection{Vascular Cell Adhesion Molecule 1}

Liver sinusoidal endothelial cells (LSECs), hepatic gatekeeper cells, play critical roles in liver diseases as discussed in our previous publication, including NAFLD, liver fibrosis, cirrhosis, and HCC [48]. Hepatic infiltration of inflammatory monocytes and lymphocytes is of critical importance in liver injury. Under the lipotoxic condition, the expression of vascular cell adhesion molecule 1 (VCAM-1) on LSECs is significantly increased in murine and human NASH [49], which mediates the migration of inflammatory cells and results in the progression of NASH [50]. In addition, the serum level of VCAM-1 is an independent marker to predict advanced liver fibrosis $(\geq F 2)$ in NAFLD patients, showing a sensitivity of $80 \%$ and specificity of $83 \%$ at the cutoff point of $13.2 \mathrm{ng} / \mathrm{mL}$ [51].

\subsection{Glucagon-Like Peptide-1}

Glucagon-like peptide-1 (GLP-1) receptor agonists have been approved for the treatment of type 2 diabetes and obesity. Intraperitoneal treatment of a synthetic peptide AWRK6, a candidate agonist of GLP-1, can improve hepatic steatosis, glucose metabolism, and obesity in high energy diet (HED)-induced MAFLD mice, via modulating phosphoinositide 3-kinase (PI3K) / Protein kinase B (AKT)/AMP-activated protein kinase (AMPK)/ acetyl-CoA carboxylase (ACC) signaling pathway [52]. In diabetic fatty rats, GLP-1 agonists liraglutide and Ex-4 can enhance the expression of PPAR $\alpha$ through a GLP-1 receptor/AMPK signaling pathway [53]. However, a cohort study showed that the treatment of GLP-1 agonist did not decrease the risk of NAFLD development compared to insulin treatment [54]. Therefore, more studies are needed to clarify the therapeutic role of GLP-1 in NAFLD.

\subsection{MicroRNAs}

The microRNAs (miRNAs) of epigenetic factors play essential roles in each step of the development and progression of NAFLD. For example, liver-specific miR-21 depletion can inhibit obesogenic diet-induced steatosis and glucose intolerance in mice [55]. Inhibiting miR-21 expression can also suppress a methionine-choline-deficient (MCD) diet-induced liver inflammation and fibrosis by recovering the function of $P P A R \alpha$, evidenced by loss of function of inhibitor of miR-21 in PPAR $\alpha$-deficient mice [56]. Different miRNAs can modulate different molecules or signaling pathways to impact the progression of NAFLD and NASH, which are summarized in Table 1. 
Table 1. The miRNAs-mediated function and therapy in NAFLD.

\begin{tabular}{|c|c|c|c|}
\hline miRNAs & Target & Function & Reference \\
\hline$m i R-21$ & PPAR $\alpha$ & $\begin{array}{l}\text { In a diet-induced NASH model, miR- } 21 \text { ablation ameliorated the progression } \\
\text { of hepatic steatosis, apoptosis, and fibrosis via inhibiting the expression } \\
\text { of PPAR } \alpha \text {. }\end{array}$ & [57] \\
\hline$m i R-29 a$ & $H M G C R$ & $\begin{array}{l}\text { Overexpression of miR-29a in steatosis hepatic SMMC-7721 cells significantly } \\
\text { reduced the accumulation of free cholesterol and the expression of } \\
\text { 3-hydroxy-3-methylglutaryl coenzyme A reductase (HMGCR), a } \\
\text { rate-limiting enzyme of cholesterol synthesis in the liver. Furthermore, the } \\
\text { expression of } m i R-29 a \text { was inversely correlated with } H M G C R \text { expression in } \\
\text { MCD-fed mice and two steatosis hepatic cell models (SMMC-7721 and } \\
\text { HL-7702 cells), indicating that } m i R-29 a \text { can be utilized as a potential } \\
\text { therapeutic target for the treatment of NAFLD. }\end{array}$ & [58] \\
\hline$m i R-34 a$ & PPAR $\alpha$ & $\begin{array}{l}\text { Inhibition of } m i R-34 a \text { expression suppressed lipid accumulation and } \\
\text { improved the degree of steatosis, ameliorating the development of NAFLD } \\
\text { by targeting PPAR } \alpha \text {. }\end{array}$ & [59] \\
\hline$m i R-122$ & Sirt1 & $\begin{array}{l}\text { Knockdown of miR-122 effectively decreased excessive lipid production and } \\
\text { suppressed the expression of lipogenic genes in FFA-treated HepG2 and } \\
\text { Huh-7 cells via upregulating Sirt1 by binding to its 3'-untranslated region } \\
\text { (UTR). In addition, miR-122 knockdown activated the liver Kinase B1 } \\
\text { (LKB1)/AMPK signaling pathway. }\end{array}$ & [60] \\
\hline $\begin{array}{c}m i R-146 a- \\
5 p\end{array}$ & ROCK1 & $\begin{array}{l}\text { It has been reported that nuclear enriched abundant transcript } 1 \text { (NEAT1) } \\
\text { was significantly upregulated in the NAFLD model. NEAT1 regulates the } \\
\text { expression of miR-146a-5p that targets ROCK1 (rho-associated, } \\
\text { coiled-coil-containing protein kinase } 1 \text { ), which further affects the } \\
A M P K / S R E B P \text { pathway. }\end{array}$ & [61] \\
\hline$m i R-181 a$ & $P P A R \alpha$ & $\begin{array}{l}\text { Inhibition of miR-181a expression resulted in the upregulation of } P P A R \alpha \\
\text { signaling pathway and inhibited palmitic acid (PA)-induced lipid } \\
\text { accumulation in hepatocytes. The upregulation of } m i R-181 a \text { showed a } \\
\text { reverse effect in hepatocyte lipid accumulation. Meanwhile, upregulating } \\
P P A R \alpha \text { abrogated miR-181a mimics-induced lipid accumulation in } \\
\text { hepatocytes. This study suggests that the downregulation of miR-181a may } \\
\text { improve lipid metabolism in NAFLD. }\end{array}$ & [62] \\
\hline$m i R-192-5 p$ & $S C D-1$ & $\begin{array}{l}\text { In PA-treated Huh7 cells, overexpression of miR-192-5p significantly reduced } \\
\text { lipid accumulation, which was abrogated by stearoyl-CoA desaturase } 1 \\
(S C D-1) \text { siRNA. Transfection of } m i R-192-5 p \text { mimic and inhibitor in Huh7 cells } \\
\text { dramatically repressed and promoted } S C D-1 \text { protein expression, respectively. }\end{array}$ & [63] \\
\hline$m i R-205$ & NEU1 & $\begin{array}{l}\text { MiR-205 expression was inversely correlated with neuraminidase } 1 \text { (NEU1) } \\
\text { expression in both HFD-fed mice and oleic acid (OA)-treated HepG2 and PH } \\
\text { cells. In HFD-fed mice, overexpression of } m i R-205 \text { resulted in a decrease in } \\
\text { body weight, liver weight and triglyceride, and lipid accumulation. The } \\
\text { in vitro study indicated that overexpression of miR-205 ameliorated lipid } \\
\text { accumulation in OA-induced HepG } 2 \text { and PH cells by targeting NEU1, } \\
\text { identified by the TargetScan analysis and Luciferase assay. Knockdown of } \\
\text { NEU1 reduced lipid accumulation in vivo, suggesting that miR-205 might be } \\
\text { a therapeutic target for NAFLD. }\end{array}$ & [64] \\
\hline$m i R-873-5 p$ & GNMT & $\begin{array}{l}\text { In hepatocytes of a preclinical murine NASH model, miR-873-5p controlled } \\
\text { the enzyme glycine N-methyltransferase (GNMT) expression, which } \\
\text { mediates mitochondrial functionality. Upregulation of } m i R-873-5 p \text { was also } \\
\text { shown in the liver of NAFLD/NASH patients, correlating with hepatic } \\
\text { GNMT depletion. Treatment with anti-miR- } 873-5 p \text { resolved lipid } \\
\text { accumulation, inflammation, and fibrosis by enhancing fatty acid } \\
\beta \text {-oxidation in the mitochondria, suggesting that miR-873-5p inhibitor } \\
\text { emerges as a potential treatment for NASH. }\end{array}$ & [65] \\
\hline
\end{tabular}




\section{Serum Marker for the Diagnosis of NAFLD and NASH}

NAFLD is a broad spectrum of liver disease, ranging from early steatosis to NASH with advanced liver inflammation and fibrosis. The basis of treatment is dependent on the stage of NAFLD. Therefore, early diagnosis of NAFLD and the advanced stage of NASH is critically important for selecting appropriate treatment. Currently, liver biopsy is the gold standard for NAFLD diagnosis [66]. However, it is invasive and expensive and may cause improper diagnosis due to sampling bias [1]. Multi-omics have been used to investigate new non-invasive markers for the diagnosis of NAFLD and advanced liver disease $[67,68]$. A significant reduction of hepatic fat with advanced liver fibrosis in patients with NASH, even to the point of complete fat loss, burnt-out NASH [69]. An increase in serum adiponectin level was significantly associated with burnt-out NASH [70]. Here, we summarize the serum markers and score system for detecting NAFLD and NASH (Table 2). Performing the analysis of the area under the receiver operating characteristic curve (AUROC) is commonly applied to evaluate the applicability of models or score systems.

Table 2. Serum markers and score system for NAFLD and NASH diagnosis.

\begin{tabular}{|c|c|c|c|}
\hline Score/Marker & Test Components & Diagnosis & References \\
\hline TG/HDL-C ratio & $\begin{array}{l}\text { Triglycerides to high-density } \\
\text { lipoprotein cholesterol ratio } \\
\text { (TG/HDL-C) }\end{array}$ & Presence of NAFLD & {$[71,72]$} \\
\hline Biglycan $(B G N)$ & $\begin{array}{l}\text { The cutoff value of } 189.58 \\
\mathrm{pg} / \mathrm{mL} \text { of serum } B G N \text { with } \\
\text { the best sensitivity }(93.55 \%) \\
\text { and specificity }(87.18 \%)\end{array}$ & $\begin{array}{c}\text { Fibrosis stage of } \\
\text { NASH }\end{array}$ & {$[73,74]$} \\
\hline NAFLD ridge score & $\begin{array}{c}\text { ALT, HDL-C, TG, } \\
\text { haemoglobin A1c, white } \\
\text { blood cell count, the presence } \\
\text { of hypertension }\end{array}$ & Presence of NAFLD & [75] \\
\hline $\begin{array}{l}\text { Hepatic steatosis } \\
\text { index (HSI) }\end{array}$ & $\begin{array}{c}8 \times(\text { ALT } / \text { AST ratio })+\text { BMI } \\
(+2, \text { if female } ;+2, \text { if diabetes } \\
\text { mellitus })\end{array}$ & Presence of NAFLD & [76] \\
\hline BARD score & $\begin{array}{l}\text { BMI, AST / ALT ratio, } \\
\text { diabetes mellitus }\end{array}$ & Presence of NAFLD & {$[77,78]$} \\
\hline FIB-4 score & Age, platelet count, ALT, AST & $\begin{array}{c}\text { Presence of NAFLD } \\
\text { or fibrosis stage of } \\
\text { NASH }\end{array}$ & [79-81] \\
\hline NAFLD fibrosis score & $\begin{array}{l}\text { Age, hyperglycemia, body } \\
\text { mass index, platelet count, } \\
\text { albumin, and AST/ALT ratio }\end{array}$ & $\begin{array}{c}\text { Presence of fibrosis in } \\
\text { NAFLD }\end{array}$ & {$[80,82]$} \\
\hline Fatty Liver Index & $\begin{array}{l}\text { BMI, waist circumference, } \\
\text { triglycerides, and } \\
\gamma \text {-glutamyltransferase }\end{array}$ & Presence of NAFLD & [83-85] \\
\hline AUROC & $\begin{array}{c}\text { Waist circumference, ALT, } \\
\text { HbA1c, and HOMA-IR }\end{array}$ & Presence of NAFLD & [86] \\
\hline
\end{tabular}

Abbreviations: ALT, alanine aminotransferase; AST, aspartate aminotransferase; AUROC, area under the receiver operating characteristic curve; BMI, body mass index; FIB-4, fibrosis-4 score; HbA1c, hemoglobin A1c; HOMA-IR, homeostasis model assessment for insulin resistance; TG, triglyceride.

\section{Treatment Options for NAFLD and NASH}

The liver is an essential organ for energy metabolism, and dysfunction of energy metabolism or metabolic syndrome impacts its function, resulting in the progression of NAFLD and NASH. Therefore, strategies modulating the change of metabolic dysfunction can be applied to treat liver diseases. 


\subsection{Lifestyle Modification}

Lifestyle modification is an effective way of prevention and treatment of NAFLD. The main purpose of lifestyle modification, such as a healthy diet and exercise, is to keep appropriate body weight.

\subsubsection{Calorie-Restricted Diet or Low-Fat Diet}

Consumption of a diet with calories less than the required daily energy, such as the Mediterranean diet, can reduce body weight, hepatic lipid accumulation, and insulin resistance, as well as decreased serum levels of saturated fatty acid and increased serum levels of monounsaturated and n-3 polyunsaturated fatty acid [87]. In a controlled clinical trial, 74 patients with NAFLD were randomized in a 1:1:1 ratio to a 12-week treatment with either a 5:2 diet with an intermittent calorie restriction $(500 \mathrm{kcal} /$ day for women and $600 \mathrm{kcal} /$ day for men) for two non-consecutive days per week, or a low-carbohydrate high-fat diet (LCHF) with an average daily calorie intake of $1600 \mathrm{kcal} /$ day for women and $1900 \mathrm{kcal} /$ day for men, or general lifestyle advice from a hepatologist by choosing a healthy diet, doing exercise, reducing alcohol, and others [88]. The results indicated that both the 5:2 diet and LCHF are more effective to reduce hepatic steatosis and body weight compared to general lifestyle modification.

Dietary intervention can also modulate the components of gut microbiota and improve the health condition of NAFLD patients [89], such as reduction of body weight and improvement of insulin resistance. Consumption of a Dietary Approaches to Stop Hypertension (DASH) diet can reduce BMI, serum markers of alanine aminotransferase (ALT), alkaline phosphatase (ALP), insulin levels, and HOMA-IR compared to the control diet [90].

\subsubsection{Exercise}

A cross-sectional study in Korea showed that adults who have long working hours (53-83 h/week) are more likely to develop NAFLD compared to those who work the standard hours (36-42 h/week), especially in women workers and workers with age $<63$ years [91]. This result was concluded after adjusting factors including age, sex, BMI, smoking, alcohol, exercise, diabetes, hypertension, and serum triglyceride and total cholesterol [91]. Another study in Japan showed that there was a significant association between working hours and metabolic syndrome in men workers age $\geq 40$ years [92]. The workers who worked $8-9 \mathrm{~h} /$ day had an odds ratio of 2.02 (95\% CI, 1.04-3.90) and those working $>10 \mathrm{~h} /$ day with an odds ratio of 3.14 (95\% CI, 1.24-7.95) in developing metabolic syndrome compared with those who worked 7-8h/day [92]. In addition, long hours compared to standard hours may increase the risk of other diseases, such as coronary heart disease [93] and stroke [94]. However, when interpreting clinical trial results or design clinical trials for lifestyle modification, introducing some uncertainties such as Hawthorne effects among participants may result in alteration of their behavior and trial results $[95,96]$. Therefore, appropriate controls are critically important in these kinds of trials.

Long-term exercise can prevent NASH development by improving the phagocytic capacity of liver resident Kupffer cells (KCs) and reducing liver inflammation and fibrogenesis [97]. A murine study showed that maternal exercise can reduce western-stylediet (WSD)-induced obesity and improve hepatic lipid metabolism via activating the AMP-activated protein kinase (AMPK) and PPAR $\gamma$-coactivator- $1 \alpha(P G C-1 \alpha)$ signaling pathways [98]. Exercise-training intervention can also reduce intrahepatic fat accumulation, blood pressure, and insulin resistance in obese adults [99]. However, the working pressure and fast-food products make the change of lifestyle very difficult or cause most people to give up in this process. 


\subsection{Bariatric Surgery}

Bariatric surgery (BS) or weight loss surgery is considered the most effective way to treat obesity and diabetes $[100,101]$, by reducing food absorption and modulating gut hormone secretion and metabolic dysfunction. A meta-analysis showed that BS can significantly reduce mortality and expand lifetime in adults with obesity compared to usual obesity management [102]. The bariatric procedures sleeve gastrectomy (SG) and Roux-en-Y gastric bypass (RYGB) on NAFLD and NASH are similarly effective, evidenced by the change of liver function tests (LFTs) after one year of surgery [103]. Other studies indicate that there are some differences induced by BS procedures [104,105]. For example, a 5-year follow-up study (a long-term effect) showed that laparoscopic Roux-en-Y gastric bypass (LRYGB) was better to improve weight loss and reduce hypertension compared to laparoscopic sleeve gastrectomy (LSG), but there was no significant difference in remission of T2DM, obstructive sleep apnoea, or improvement in quality of life, data collected from two randomized clinical trials [105]. In patients aged $\geq 65$, the effect of LRYGB on controlling weight loss, HbA1c (diabetes), and low-density lipoprotein (LDL) is better than LSG [106].

\subsection{Modification of Gut Microbiota}

Dysbiosis of gut microbiota is a causing factor for NAFLD, due to the change of gut hormones, metabolites, inflammatory factors. The abundance of some bacterial species is associated with the progression of liver disease. For example, there is a negative correlation between the severity of liver fibrosis and Eubacterium abundance in non-obese patients with NAFLD [107]. The abundance of Ruminococcaceae and Veillonellaceae is also positively associated with the severity of liver fibrosis in non-obese subjects [108]. Modulation of gut microbiota via different strategies [109], including fecal microbiota transplantation (FMT), drug therapy (e.g., antibiotics), modification of lifestyle (e.g., dietary change), the above-mentioned BS, and others can improve liver disease. A meta-analysis study showed that supplementation of probiotics can reduce the expression of inflammatory factors, such as tumor necrosis factor- $\alpha$ (TNF- $\alpha$ ) and C-reactive protein (CRP) in the livers of NAFLD patients [110]. Allogenic fecal microbiota transplantation (FMT) from thin and healthy people to patients with NAFLD can reduce the small intestinal permeability post-six-week treatment [111]. However, the effect of FMT on liver dysfunction and metabolic syndrome remains minimal. A double-blind phase 2 trial also showed that a yearly treatment of synbiotics, a combination of probiotic and prebiotic, only modulated the change of gut microbiota but not the liver fat content and fibrotic markers [112].

Furthermore, BS modulates the components of the gut microbiota profile. For example, the predominant bacteria of Bacteroides before surgery was decreased after laparoscopic gastric bypass (LGB) [113]. Both the altered bacterial profile and their associated metabolism following BS contribute to the impact on patients [114].

\subsection{Medicines}

\subsubsection{Antidiabetic and Anti-Obesity Drugs}

The incidence of NAFLD is significantly associated with T2DM and obesity, especially in patients with a higher body mass index (BMI) $[115,116]$. In contrast, the incidence of NAFLD is decreased in patients with T2DM, who received treatments such as sodiumglucose cotransporter-2 (SGLT2) inhibitors, GLP-1 receptor antagonists, and insulin [115]. The reprogramming of antidiabetic or anti-obesity drugs, such as pioglitazone and saroglitazar, are being considered as the options for NAFLD/NASH treatment. Saroglitazar, a double agonist against $P P A R-\alpha / \gamma$, can reduce hepatic lipid accumulation, lobular inflammation, hepatocyte ballooning, and liver fibrosis in a mouse NASH model [117]. A phase 2 clinical trial study showed that $4 \mathrm{mg}$ of saroglitazar can significantly decrease ALT and liver fat content, improve insulin resistance and dyslipidemia in patients with NAFLD or NASH [118]. 
Farnesoid $X$ receptor $(F X R)$, a nuclear receptor that can be activated by bile acids (BAs), plays a critical role in hepatic lipid accumulation [119-121], as well as glucose homeostasis [122]. Cilofexor (GS-9674), a nonsteroidal agonist of $F X R$ with an $\mathrm{EC}_{50}$ of $43 \mathrm{nM}$, has anti-inflammatory and antifibrotic effects. A phase 2 trial study showed that cilofexor significantly improved hepatic steatosis and decreased serum $\gamma$-glutamyltransferase, C4, and primary bile acids, but not liver fibrosis and stiffness in NASH patients [123].

SGLT2 inhibitors, such as canagliflozin, dapagliflozin, and empagliflozin, have pleiotropic functions to treat NAFLD and T2DM by preventing de novo lipogenesis, liver inflammation and cell apoptosis, and increasing fatty acid oxidation [124].

GLP-1 receptor agonists can inhibit hepatic fat accumulation as the effect of metformin and insulin-based treatment [125]. In addition, they can moderately improve liver fibrosis. Metformin is the first-line treatment for patients with T2DM, which can control high blood sugar [126] and decrease total cholesterol, LDL, and triglycerides [127]. However, the effects of metformin, as well as dipeptidyl peptidase-4 (DPP-4) inhibitors in NAFLD treatment, remain debatable [128].

\subsubsection{Antioxidants}

A meta-analysis of clinical trials showed that adjuvant vitamin $\mathrm{E}$ treatment is favorable for adult patients with NAFLD compared to pediatric patients [129]. Vitamin E can also improve NASH in HIV-infected patients, evidenced by the reduction of serum biomarker ALT and cytokeratin 18 (CK-18) for hepatocyte apoptosis [130].

Polyphenols as anti-inflammatory and antioxidant reagents show a protective effect in liver disease, and consumption of polyphenol-rich diets also pride beneficial effects for NAFLD patients [131]. For example, a high intake of lignans, a large group of low molecular weight polyphenols in plants such as whole grains, reduces the incidence of NAFLD [132].

\subsubsection{Antibiotics}

Rifaximin has been used for treating hepatic encephalopathy, and it also has a protective effect against intestinal leaking [133]. A 28-day treatment of rifaximin (1200 mg/day) in NASH patients resulted in a dramatic reduction of serum endotoxin, AST, ALT, $\gamma-$ glutamyltransferase, LDL, and ferritin, and a mild reduction of the average BMI [134]. However, the effect of rifaximin on patients with simple steatosis was significantly reduced, with only effects on the reduction of ALT and ferritin [134].

\subsubsection{Anti-Cell Death Reagents}

Lipotoxicity causes hepatic cell death and promotes the progression of NAFLD and $\mathrm{NASH}$, which induces proinflammatory cytokines and chemokines and activation of hepatic stellate cells (HSCs). Therefore, inhibiting cellular death is critically important for the treatment of chronic liver disease. For example, selonsertib, a selective inhibitor of apoptosis signal-regulating kinase 1 , showed an antifibrotic effect in patients with NASH and F2-F3 liver fibrosis [135]. However, two phase 3 clinical trials showed that selonsertib monotherapy did not improve liver fibrosis in patients with NASH and bridging fibrosis (F3) or compensated cirrhosis (F4) compared to placebo control treatment [136]. In another phase 2 trial showed that a combination of selonsertib with cilofexor or firsocostat (a small molecule inhibitor of acetyl-CoA carboxylase) improved steatosis, while a combination of selonsertib with cilofexor improved the early stage of liver fibrosis (F1) [137]. These completed trials showed that selonsertib has some effects on the early stage of NASH, but not advanced liver fibrosis or cirrhosis. Metformin, a first-line antidiabetic drug, also shows a protective effect against palmitate-induced necrosis in primary rat hepatocytes by reducing reactive oxygen species (ROS) and improving mitochondrial function [138]. 


\subsubsection{Antifibrotic Reagents}

Antifibrotic reagents can prevent the progression of liver fibrosis and NAFLD to fibrotic NASH. The activated HSCs are a source of predominant extracellular matrix proteins-producing cells during liver fibrosis [139,140]. Anti-liver fibrosis methods mainly consist of inhibiting the activation and growth of HSCs, anti-inflammation, anti-cell death agents, and regulating the production of extracellular matrix (ECM) proteins. The abovementioned methods for the treatment of NAFLD or NASH are also treatment options for liver fibrosis. Some natural products have multiple effects. For example, Scoparone, a bioactive compound from a Chinese herb, can decrease hepatic steatosis, inflammation, cell death, and fibrosis in mice with diet-induced NASH [141].

In addition, there are some other targets for NAFLD and NASH treatments, such as G protein-coupled receptors (GPCRs) [142], estrogen-related receptor alpha (ERR $\alpha)$ [143], bone morphogenetic proteins (BMPs) [144], and KLFs [24,145]. The treatment options for NAFLD/NASH are summarized in the graphic picture (Figure 2). Overall, regulating liver and gut metabolism, liver inflammation, fibrosis, and cell death can effectively prevent the development of NAFLD and NASH.

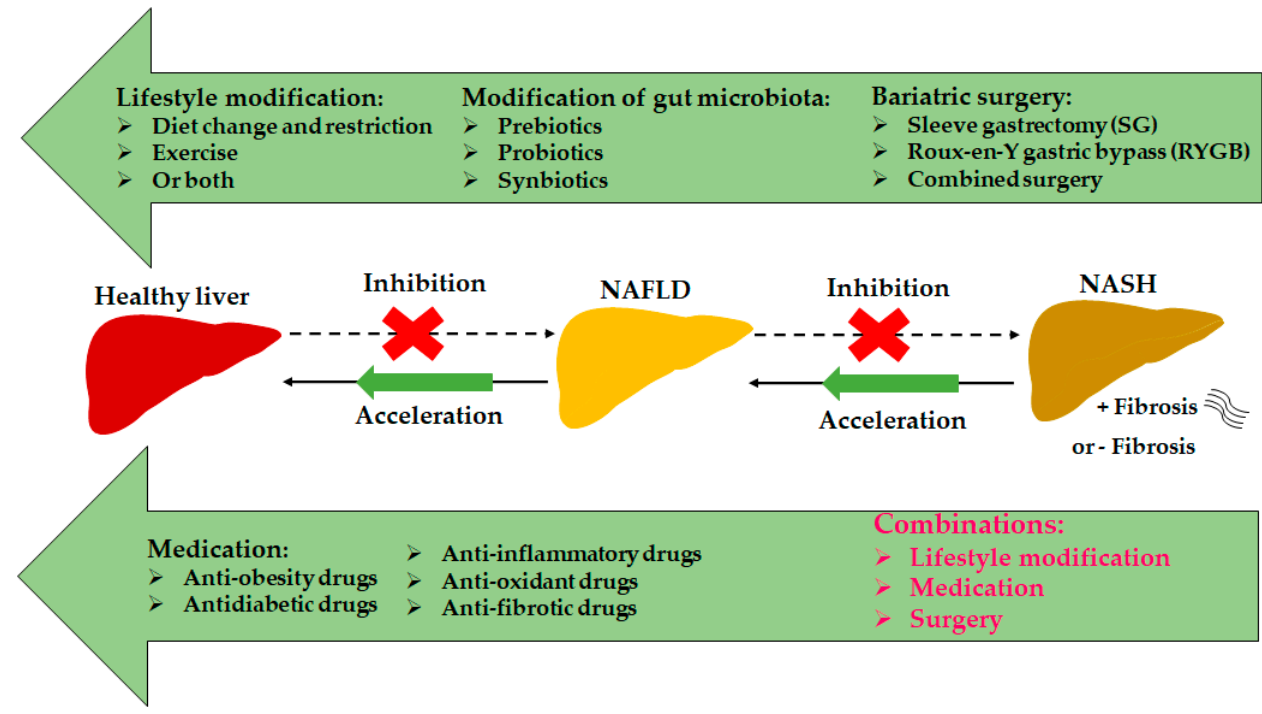

Figure 2. Treatment options for NAFLD or NASH. The currently effective treatment options for NAFLD/NASH include lifestyle modification, bariatric surgery, and medicines. In addition, modification of gut microbiota by prebiotics, probiotics, or synbiotics shows promising effects.

\section{Clinical Trials}

This review summarizes the completed clinical trials targeting the improvement of NAFLD and NASH (Table 3). The data were collected from the website https:/ / clinicaltrials.gov (accessed on 20 June 2021) with the keywords NAFLD, NASH, and treatment. The testing candidates may not provide the prospective effect as shown in preclinical studies. For example, a phase 2 clinical trial showed that GLP-1 receptor agonist semaglutide can improve NASH resolution without worsening liver fibrosis compared to placebo, but semaglutide did not significantly ameliorate liver fibrosis in NASH patients [146]. 
Table 3. The completed clinical trials for NAFLD/NASH treatment.

\begin{tabular}{|c|c|c|c|c|}
\hline $\begin{array}{c}\text { Liver } \\
\text { Disease }\end{array}$ & Treatment & Target & Trials & References \\
\hline $\begin{array}{l}\text { NAFLD } \\
\text { NASH }\end{array}$ & MSDC-0602K & $\begin{array}{l}\text { Two higher doses of MSDC-0602K ( } 125 \mathrm{mg} \text { and } 250 \mathrm{mg} \text { ), a } \\
\text { second-generation thiazolidinedione (TZD) significantly } \\
\text { reduced the levels of glucose, glycated hemoglobin, insulin, } \\
\text { liver enzymes, and NAS compared to placebo. }\end{array}$ & NCT02784444 & [147] \\
\hline NAFLD & Volixibat & $\begin{array}{l}\text { Treatment with volixibat for } 12 \text { days, a selective inhibitor of } \\
\text { the apical sodium-dependent bile acid transporter, can inhibit } \\
\text { bile acid reabsorption in overweight and obese adults. }\end{array}$ & NCT02287779 & [148] \\
\hline NASH & $\begin{array}{l}\text { Cilofexor } \\
\text { (GS-9674) }\end{array}$ & $\begin{array}{l}\text { Therapy with Cilofexor for } 24 \text { weeks, a nonsteroidal agonist of } \\
\text { FXR, was well-tolerated and provided significant reductions in } \\
\text { hepatic steatosis, liver biochemistry, and serum bile acids in } \\
\text { patients with NASH. }\end{array}$ & NCT02854605 & [149] \\
\hline NASH & Vitamin E & $\begin{array}{l}\text { Vitamin E can decrease serum ALT levels and NAS score, but } \\
\text { not liver fibrosis. }\end{array}$ & NCT00063622 & [150] \\
\hline NAFLD & Vitamin E & $\begin{array}{l}\text { Treatment with vitamin } \mathrm{E} \text { ( } \alpha \text {-tocopherol, } \alpha \mathrm{T} \text { ) improved liver } \\
\text { injury and steatosis. }\end{array}$ & NCT01792115 & [151] \\
\hline NASH & $\begin{array}{l}\text { Firsocostat } \\
(\text { GS-0976) }\end{array}$ & $\begin{array}{l}\text { Treatment with GS-0976 for } 12 \text { weeks dramatically decreased } \\
\text { serum level of ALT, liver de novo lipogenesis (DNL), steatosis, } \\
\text { and stiffness. }\end{array}$ & NCT02856555 & {$[152,153]$} \\
\hline NASH & $\begin{array}{l}\text { Pegbelfermin } \\
\text { (BMS-986036) }\end{array}$ & $\begin{array}{l}\text { Administration of Pegbelfermin for } 16 \text { weeks, a PEGylated } \\
\text { human fibroblast growth factor } 21 \text { (FGF21) analogue, was } \\
\text { generally well tolerated and significantly decreased liver fat. }\end{array}$ & NCT02413372 & [154] \\
\hline NAFLD & $\begin{array}{l}\text { Obeticholic } \\
\text { acid (OCA) }\end{array}$ & $\begin{array}{l}\text { Treatment with FXR agonist OCA for } 6 \text { weeks improved } \\
\text { insulin sensitivity and decreased markers of liver } \\
\text { inflammation and fibrosis in patients with T2DM and NAFLD. }\end{array}$ & NCT00501592 & [155] \\
\hline NASH & Losartan & $\begin{array}{l}\text { Treatment with losartan, an angiotensin II receptor blocker, } \\
\text { improvement in alanine ALT, AST, and HOMA-IR compared } \\
\text { to the placebo. }\end{array}$ & NCT01913470 & [156] \\
\hline NASH & Silymarin & $\begin{array}{l}\text { Treatment with silymarin, an extract of milk thistle, did not } \\
\text { significantly improve NAFLD Activity Score (NAS) and liver } \\
\text { fibrosis. }\end{array}$ & NCT00680407 & [157] \\
\hline NASH & Metformin & $\begin{array}{l}\text { Forty-eight weeks of metformin ( } 2000 \mathrm{mg} / \text { day) therapy } \\
\text { improved NASH activity index and ALT levels, and reduced } \\
\text { bodyweight. }\end{array}$ & NCT00063232 & [158] \\
\hline NASH & $\begin{array}{l}\text { Cenicriviroc } \\
\quad(\mathrm{CVC})\end{array}$ & $\begin{array}{l}\text { Therapy with Cenicriviroc, CCR } 2 \text { and CCR } 5 \text { dual antagonist, } \\
\text { showed an antifibrotic effect without impacting steatohepatitis } \\
\text { at year } 1 \text { in responders, which was maintained in year } 2 \text { with } \\
\text { greater effect in advanced fibrosis. }\end{array}$ & NCT02217475 & [159] \\
\hline NASH & $\begin{array}{l}\text { Pentoxifylline } \\
\quad \text { (PTX) }\end{array}$ & $\begin{array}{l}\text { Pentoxifylline, a competitive nonselective phosphodiesterase } \\
\text { inhibitor, can improve liver steatosis and AST, ALT in patients } \\
\text { with NASH compared to the baseline. }\end{array}$ & NCT00267670 & [160] \\
\hline NAFLD & $\begin{array}{l}\text { Low free } \\
\text { sugar diet }\end{array}$ & $\begin{array}{l}\text { Eight weeks of use of a low-free sugar diet in adolescent boys } \\
\text { with NAFLD resulted in significant improvement in hepatic } \\
\text { steatosis compared to the usual diet. }\end{array}$ & NCT02513121 & [161] \\
\hline NAFLD & Synbiotics & $\begin{array}{l}\text { Administration of a synbiotic combination of probiotic and } \\
\text { prebiotic for one year changed gut microbiota but did not } \\
\text { reduce liver fat content or markers of liver fibrosis. }\end{array}$ & NCT01680640 & [112] \\
\hline NAFLD & Emricasan & $\begin{array}{l}\text { Treatment with Emricasan, a pan-caspase inhibitor, caused a } \\
\text { reduction of ALT and cleaved cytokeratin-18, full-length } \\
\text { cytokeratin- } 18 \text {, and caspase } 3 / 7 \text { in patients with NAFLD at } \\
\text { day } 7 \text { and day } 28 \text { post-treatment. }\end{array}$ & NCT02077374 & [162] \\
\hline
\end{tabular}


This review summarizes the completed clinical trials targeting the improvement of NAFLD and NASH (Table 3). The data were collected from the website https:/ / clinicaltrials.gov (accessed on 20 June 2021) with the keywords NAFLD, NASH, and treatment. The testing candidates may not provide the prospective effect as shown in preclinical studies. For example, a phase 2 clinical trial showed that GLP-1 receptor agonist semaglutide can improve NASH resolution without worsening liver fibrosis compared to placebo, but semaglutide did not significantly ameliorate liver fibrosis in NASH patients [146].

\section{Conclusions}

The incidence of NAFLD and NASH is increasing currently, which is positively associated with the prevalence of obesity and diabetes. NAFLD and NASH are the major increasing factors that contribute to the progression of HCC, the primary liver cancer. However, there is no currently approved treatment for NAFLD and NASH. New noninvasive diagnostic markers such miRNAs have been evaluated for future diagnosis of NAFLD. Early diagnosis of the progression of NAFLD to liver fibrosis, cirrhosis, or HCC is critically important due to irreversible or difficulty to reverse of server liver disease. Some key molecules such as PPARs, GLP-1, miRNAs, and KLFs are potential targets for the treatment of metabolic diseases including NAFLD and NASH. Preclinical studies and clinical trials have been processed to evaluate potential treatment options for NAFLD and $\mathrm{NASH}$, including synbiotics, pan-caspase inhibitors, CCR2/5 antagonists, FXR agonists, and so on. A combined treatment such as combined medical treatment and physical activity could reduce the treatment time and improve the outcome.

Author Contributions: Conceptualization and data collection, C.Z. and M.Y.; writing-original draft preparation, C.Z. and M.Y.; writing-review and editing, C.Z. and M.Y. Both authors have read and agreed to the published version of the manuscript.

Funding: This research received no external funding.

Institutional Review Board Statement: Not applicable.

Informed Consent Statement: Not applicable.

Data Availability Statement: All the data supporting reported results can be found in the paper.

Conflicts of Interest: The authors declare no conflict of interest.

\section{References}

1. Castera, L.; Friedrich-Rust, M.; Loomba, R. Noninvasive Assessment of Liver Disease in Patients with Nonalcoholic Fatty Liver Disease. Gastroenterology 2019, 156, 1264-1281.e4. [CrossRef]

2. Eslam, M.; Newsome, P.N.; Sarin, S.K.; Anstee, Q.M.; Targher, G.; Romero-Gomez, M.; Zelber-Sagi, S.; Wong, V.W.-S.; Dufour, J.-F.; Schattenberg, J.M.; et al. A new definition for metabolic dysfunction-associated fatty liver disease: An international expert consensus statement. J. Hepatol. 2020, 73, 202-209. [CrossRef]

3. Liu, J.; Ayada, I.; Zhang, X.; Wang, L.; Li, Y.; Wen, T.; Ma, Z.; Bruno, M.J.; de Knegt, R.J.; Cao, W.; et al. Estimating global prevalence of metabolic dysfunction-associated fatty liver disease in overweight or obese adults. Clin. Gastroenterol. Hepatol. 2021. [CrossRef]

4. Lazarus, J.V.; Palayew, A.; Carrieri, P.; Ekstedt, M.; Marchesini, G.; Novak, K.; Ratziu, V.; Romero-Gómez, M.; Tacke, F.; Zelber-Sagi, S.; et al. European 'NAFLD Preparedness Index'-Is Europe ready to meet the challenge of fatty liver disease? JHEP Rep. 2021, 3, 100234. [CrossRef] [PubMed]

5. Dongiovanni, P.; Paolini, E.; Corsini, A.; Sirtori, C.R.; Ruscica, M. Nonalcoholic fatty liver disease or metabolic dysfunctionassociated fatty liver disease diagnoses and cardiovascular diseases: From epidemiology to drug approaches. Eur. J. Clin. Investig. 2021, 51, e13519. [CrossRef] [PubMed]

6. Fan, J.-G.; Kim, S.-U.; Wong, V.W.-S. New trends on obesity and NAFLD in Asia. J. Hepatol. 2017, 67, 862-873. [CrossRef] [PubMed]

7. Del Campo, J.A.; Gallego-Durán, R.; Gallego, P.; Grande, L. Genetic and Epigenetic Regulation in Nonalcoholic Fatty Liver Disease (NAFLD). Int. J. Mol. Sci. 2018, 19, 911. [CrossRef]

8. Jonas, W.; Schürmann, A. Genetic and epigenetic factors determining NAFLD risk. Mol. Metab. 2020, 101111. [CrossRef] 
9. Lisboa, Q.C.; Nardelli, M.J.; Pereira, P.D.A.; Miranda, D.M.; Ribeiro, S.N.; Costa, R.S.N.; Versiani, C.A.; Vidigal, P.V.T.; Ferrari, T.C.D.A.; Couto, C.A. PNPLA3 and TM6SF2 polymorphisms in Brazilian patients with nonalcoholic fatty liver disease. World J. Hepatol. 2020, 12, 792-806. [CrossRef]

10. Mazo, D.F.; Malta, F.M.; Stefano, J.T.; Salles, A.P.M.; Gomes-Gouvea, M.S.; Nastri, A.C.S.; Almeida, J.R.; Pinho, J.R.R.; Carrilho, F.J.; Oliveira, C.P. Validation of PNPLA3 polymorphisms as risk factor for NAFLD and liver fibrosis in an admixed population. Ann. Hepatol. 2019, 18, 466-471. [CrossRef] [PubMed]

11. Hardy, T.; Zeybel, M.; Day, C.P.; Dipper, C.; Masson, S.; McPherson, S.; Henderson, E.; Tiniakos, D.; White, S.; French, J.; et al. Plasma DNA methylation: A potential biomarker for stratification of liver fibrosis in non-alcoholic fatty liver disease. Gut 2017, 66, 1321-1328. [CrossRef]

12. Tian, Y.; Arai, E.; Makiuchi, S.; Tsuda, N.; Kuramoto, J.; Ohara, K.; Takahashi, Y.; Ito, N.; Ojima, H.; Hiraoka, N.; et al. Aberrant DNA methylation results in altered gene expression in non-alcoholic steatohepatitis-related hepatocellular carcinomas. J. Cancer Res. Clin. Oncol. 2020, 146, 2461-2477. [CrossRef]

13. Hyun, J.; Jung, Y. DNA Methylation in Nonalcoholic Fatty Liver Disease. Int. J. Mol. Sci. 2020, 21, 8138. [CrossRef]

14. Eslam, M.; Valenti, L.; Romeo, S. Genetics and epigenetics of NAFLD and NASH: Clinical impact. J. Hepatol. 2018, 68, 268-279. [CrossRef]

15. Liu, D.; Wang, K.; Li, K.; Xu, R.; Chang, X.; Zhu, Y.; Sun, P.; Han, X. Ets-1 deficiency alleviates nonalcoholic steatohepatitis via weakening TGF- $\beta 1$ signaling-mediated hepatocyte apoptosis. Cell Death Dis. 2019, 10, 458. [CrossRef]

16. Yun, Y.; Feng, L.; Hao, Q. Secreted modular calcium-binding protein 2 promotes high fat diet (HFD)-induced hepatic steatosis through enhancing lipid deposition, fibrosis and inflammation via targeting TGF- $\beta 1$. Biochem. Biophys. Res. Commun. 2019, 509, 48-55. [CrossRef]

17. Lai, C.-Y.; Yeh, K.-Y.; Lin, C.-Y.; Hsieh, Y.-W.; Lai, H.-H.; Chen, J.-R.; Hsu, C.-C.; Her, G. MicroRNA-21 Plays Multiple Oncometabolic Roles in the Process of NAFLD-Related Hepatocellular Carcinoma via PI3K/AKT, TGF- $\beta$, and STAT3 Signaling. Cancers 2021, 13, 940. [CrossRef] [PubMed]

18. Nair, B.; Nath, L.R. Inevitable role of TGF- $\beta 1$ in progression of nonalcoholic fatty liver disease. J. Recept. Signal Transduct. 2020, 40, 195-200. [CrossRef] [PubMed]

19. Wagner, N.; Wagner, K.-D. The Role of PPARs in Disease. Cells 2020, 9, 2367. [CrossRef] [PubMed]

20. Torres, D.M.; Jones, F.J.; Shaw, J.C.; Williams, C.D.; Ward, J.A.; Harrison, S.A. Rosiglitazone versus rosiglitazone and metformin versus rosiglitazone and losartan in the treatment of nonalcoholic steatohepatitis in humans: A 12-month randomized, prospective, open- label trial. Hepatology 2011, 54, 1631-1639. [CrossRef]

21. Lee, Y.-H.; Kim, J.H.; Kim, S.R.; Jin, H.Y.; Rhee, E.-J.; Cho, Y.M.; Lee, B.-W. Lobeglitazone, a Novel Thiazolidinedione, Improves Non-Alcoholic Fatty Liver Disease in Type 2 Diabetes: Its Efficacy and Predictive Factors Related to Responsiveness. J. Korean Med. Sci. 2017, 32, 60-69. [CrossRef]

22. Ratziu, V.; Harrison, S.A.; Francque, S.; Bedossa, P.; Lehert, P.; Serfaty, L.; Romero-Gomez, M.; Boursier, J.; Abdelmalek, M.; Caldwell, S.; et al. Elafibranor, an Agonist of the Peroxisome Proliferator-Activated Receptor $-\alpha$ and $-\delta$, Induces Resolution of Nonalcoholic Steatohepatitis without Fibrosis Worsening. Gastroenterology 2016, 150, 1147-1159.e5. [CrossRef]

23. Liu, L.; Liu, C.; Zhao, M.; Zhang, Q.; Lu, Y.; Liu, P.; Yang, H.; Yang, J.; Chen, X.; Yao, Y. The pharmacodynamic and differential gene expression analysis of PPAR $\alpha / \delta$ agonist GFT505 in CDAHFD-induced NASH model. PLoS ONE 2020, 15, e0243911. [CrossRef]

24. Lee, J.; Oh, A.-R.; Lee, H.-Y.; Moon, Y.-A.; Lee, H.-J.; Cha, J.-Y. Deletion of KLF10 Leads to Stress-Induced Liver Fibrosis upon High Sucrose Feeding. Int. J. Mol. Sci. 2020, 22, 331. [CrossRef]

25. Zhou, L.; Li, Q.; Chen, A.; Liu, N.; Chen, N.; Chen, X.; Zhu, L.; Xia, B.; Gong, Y.; Chen, X. KLF15-activating Twist2 ameliorated hepatic steatosis by inhibiting inflammation and improving mitochondrial dysfunction via NF- $\kappa B-F G F 21$ or SREBP1c-FGF21 pathway. FASEB J. 2019, 33, 14254-14269. [CrossRef] [PubMed]

26. Bechmann, L.; Vetter, D.; Ishida, J.; Hannivoort, R.A.; Lang, U.E.; Kocabayoglu, P.; Fiel, M.I.; Muñoz, U.; Patman, G.L.; Ge, F.; et al. Post-transcriptional activation of PPAR alpha by KLF6 in hepatic steatosis. J. Hepatol. 2013, 58, 1000-1006. [CrossRef]

27. Biddinger, S.B.; Hernandez-Ono, A.; Rask-Madsen, C.; Haas, J.T.; Aleman, J.; Suzuki, R.; Scapa, E.F.; Agarwal, C.; Carey, M.C.; Stephanopoulos, G.; et al. Hepatic Insulin Resistance Is Sufficient to Produce Dyslipidemia and Susceptibility to Atherosclerosis. Cell Metab. 2008, 7, 125-134. [CrossRef] [PubMed]

28. Smith, G.; Polidori, D.C.; Yoshino, M.; Kearney, M.L.; Patterson, B.W.; Mittendorfer, B.; Klein, S. Influence of adiposity, insulin resistance, and intrahepatic triglyceride content on insulin kinetics. J. Clin. Investig. 2020, 130, 3305-3314. [CrossRef]

29. Fawzy, M.H.; Saeed, N.M.; El-Sherbiny, D.A.; El-Demerdash, E. Eugenol modulates insulin sensitivity by upregulating insulin receptor substrate-2 in non-alcoholic fatty liver disease in rats. J. Pharm. Pharmacol. 2021, 73, 846-854. [CrossRef] [PubMed]

30. Kamm, D.R.; Pyles, K.D.; Sharpe, M.C.; Healy, L.N.; Colca, J.R.; McCommis, K.S. Novel insulin sensitizer MSDC-0602K improves insulinemia and fatty liver disease in mice, alone and in combination with liraglutide. J. Biol. Chem. 2021, 296, 100807. [CrossRef]

31. Smith, U. Pioglitazone: Mechanism of action. Int. J. Clin. Pr. Suppl. 2001, 121, 13-18.

32. Panunzi, S.; Maltese, S.; Verrastro, O.; Labbate, L.; De Gaetano, A.; Pompili, M.; Capristo, E.; Bornstein, S.R.; Mingrone, G. Pioglitazone and bariatric surgery are the most effective treatments for non-alcoholic steatohepatitis: A hierarchical network meta-analysis. Diabetes Obes. Metab. 2021, 23, 980-990. [CrossRef] [PubMed]

33. Kulkarni, S.; Huang, J.; Tycksen, E.; Cliften, P.F.; Rudnick, D.A. Diet Modifies Pioglitazone's Influence on Hepatic PPAR $\gamma$ Regulated Mitochondrial Gene Expression. PPAR Res. 2020, 2020, 1-20. [CrossRef] [PubMed] 
34. He, S.; Lu, Y.; Liu, X.; Huang, X.; Keller, E.T.; Qian, C.-N.; Zhang, J. Wht3a: Functions and implications in cancer. Chin. J. Cancer 2015, 34, 1-9. [CrossRef]

35. Carotenuto, P.; Fassan, M.; Pandolfo, R.; Lampis, A.; Vicentini, C.; Cascione, L.; Paulus-Hock, V.; Boulter, L.; Guest, R.; Quagliata, L.; et al. Wht signalling modulates transcribed-ultraconserved regions in hepatobiliary cancers. Gut 2016, 66, $1268-1277$. [CrossRef] [PubMed]

36. Quan, H.; Li, B.; Yang, J. MicroRNA-504 functions as a tumor suppressor in hepatocellular carcinoma through inhibiting Frizzled-7-mediated-Wnt/ $\beta$-catenin signaling. Biomed. Pharmacother. 2018, 107, 754-762. [CrossRef]

37. Teratani, T.; Tomita, K.; Suzuki, T.; Furuhashi, H.; Irie, R.; Nishikawa, M.; Yamamoto, J.; Hibi, T.; Miura, S.; Minamino, T.; et al. Aortic carboxypeptidase-like protein, a WNT ligand, exacerbates nonalcoholic steatohepatitis. J. Clin. Investig. 2018, 128, 1581-1596. [CrossRef]

38. Zhu, L.; Baker, S.S.; Shahein, A.; Choudhury, S.; Liu, W.; Bhatia, T.; Baker, R.D.; Lee, T. Upregulation of non-canonical Wnt ligands and oxidative glucose metabolism in NASH induced by methionine-choline deficient diet. Trends Cell Mol. Biol. 2018, 13, 47-56. [CrossRef]

39. Alshehri, A.S.; El-Kott, A.F.; El-Kenawy, A.E.; Khalifa, H.S.; AlRamlawy, A.M. Cadmium chloride induces non-alcoholic fatty liver disease in rats by stimulating miR-34a/SIRT1/FXR/p53 axis. Sci. Total Environ. 2021, 784, 147182. [CrossRef]

40. Xu, Y.; Zhu, Y.; Hu, S.; Xu, Y.; Stroup, D.; Pan, X.; Bawa, F.C.; Chen, S.; Gopoju, R.; Yin, L.; et al. Hepatocyte Nuclear Factor $4 \alpha$ Prevents the Steatosis-to-NASH Progression by Regulating p53 and Bile Acid Signaling (in mice). Hepatology 2021, 73, $2251-2265$. [CrossRef]

41. Zhang, X.; Lin, Y.; Lin, S.; Li, C.; Gao, J.; Feng, Z.; Wang, J.; Zhang, J.; Zhang, H.; Zhang, Y.; et al. Silencing of functional p53 attenuates NAFLD by promoting HMGB1-related autophagy induction. Hepatol. Int. 2020, 14, 828-841. [CrossRef]

42. Liu, Y.; Wang, M.; Xu, W.; Zhang, H.; Qian, W.; Li, X.; Cheng, X. Active vitamin D supplementation alleviates initiation and progression of nonalcoholic fatty liver disease by repressing the $p 53$ pathway. Life Sci. 2020, 241, 117086. [CrossRef]

43. Porteiro, B.; Fondevila, M.F.; Buque, X.; Gonzalez-Rellan, M.J.; Fernandez, U.; Mora, A.; Beiroa, D.; Senra, A.; Gallego, R.; Fernø, J.; et al. Pharmacological stimulation of $p 53$ with low-dose doxorubicin ameliorates diet-induced nonalcoholic steatosis and steatohepatitis. Mol. Metab. 2018, 8, 132-143. [CrossRef]

44. Nishizawa, H.; Iguchi, G.; Fukuoka, H.; Takahashi, M.; Suda, K.; Bando, H.; Matsumoto, R.; Yoshida, K.; Odake, Y.; Ogawa, W.; et al. IGF-I induces senescence of hepatic stellate cells and limits fibrosis in a p53-dependent manner. Sci. Rep. 2016, 6, 34605. [CrossRef] [PubMed]

45. Dattaroy, D.; Seth, R.K.; Sarkar, S.; Kimono, D.; Albadrani, M.; Chandrashekaran, V.; Al Hasson, F.; Singh, U.P.; Fan, D.; Nagarkatti, M.; et al. Sparstolonin B (SsnB) attenuates liver fibrosis via a parallel conjugate pathway involving P53-P21 axis, TGF-beta signaling and focal adhesion that is TLR4 dependent. Eur. J. Pharmacol. 2018, 841, 33-48. [CrossRef]

46. Luo, Y.-D.; Fang, L.; Yu, H.-Q.; Zhang, J.; Lin, X.-T.; Liu, X.-Y.; Wu, D.; Li, G.-X.; Huang, D.; Zhang, Y.-J.; et al. p53 haploinsufficiency and increased $m$ TOR signalling define a subset of aggressive hepatocellular carcinoma. J. Hepatol. 2021, 74, 96-108. [CrossRef] [PubMed]

47. Chang, Y.; Liu, B.; Niu, H.; Wang, Z.; Xia, S.; Li, H. Value of anti-p53 antibody as a biomarker for hepatocellular carcinoma. Medicine 2020, 99, e21887. [CrossRef] [PubMed]

48. Ming, Y.; Zhang, C. The role of liver sinusoidal endothelial cells in cancer liver metastasis. Am. J. Cancer Res. 2021, 11, 1845-1860.

49. Furuta, K.; Guo, Q.; Pavelko, K.D.; Lee, J.-H.; Robertson, K.D.; Nakao, Y.; Melek, J.; Shah, V.H.; Hirsova, P.; Ibrahim, S.H. Lipid-induced endothelial vascular cell adhesion molecule 1 promotes nonalcoholic steatohepatitis pathogenesis. J. Clin. Investig. 2021, 131, e143690. [CrossRef]

50. Carr, R.M. VCAM-1: Closing the gap between lipotoxicity and endothelial dysfunction in nonalcoholic steatohepatitis. J. Clin. Investig. 2021, 131, e147556. [CrossRef]

51. Lefere, S.; Van De Velde, F.; Devisscher, L.; Bekaert, M.; Raevens, S.; Verhelst, X.; Van Nieuwenhove, Y.; Praet, M.; Hoorens, A.; Van Steenkiste, C.; et al. Serum vascular cell adhesion molecule-1 predicts significant liver fibrosis in non-alcoholic fatty liver disease. Int. J. Obes. 2017, 41, 1207-1213. [CrossRef] [PubMed]

52. Jin, L.; Sun, Y.; Li, Y.; Zhang, H.; Yu, W.; Li, Y.; Xin, Y.; Alsareii, S.A.; Wang, Q.; Zhang, D. A synthetic peptide AWRK6 ameliorates metabolic associated fatty liver disease: Involvement of lipid and glucose homeostasis. Peptides 2021, 143, 170597. [CrossRef] [PubMed]

53. Zhou, R.; Lin, C.; Cheng, Y.; Zhuo, X.; Li, Q.; Xu, W.; Zhao, L.; Yang, L. Liraglutide Alleviates Hepatic Steatosis and Liver Injury in T2MD Rats via a GLP-1R Dependent AMPK Pathway. Front. Pharmacol. 2021, 11, 600175. [CrossRef]

54. Van Dalem, J.; Driessen, J.H.; Burden, A.M.; Stehouwer, C.D.; Klungel, O.H.; de Vries, F.; Brouwers, M.C. Thiazolidinediones and Glucagon-like Peptide-1 Receptor Agonists and the Risk of Nonalcoholic Fatty Liver Disease: A Cohort Study. Hepatology 2021. [CrossRef]

55. Calo, N.; Ramadori, P.; Sobolewski, C.; Romero, Y.; Maeder, C.; Fournier, M.; Rantakari, P.; Zhang, F.-P.; Poutanen, M.; Dufour, J.-F.; et al. Stress-activated $m i R-21 / m i R-21^{*}$ in hepatocytes promotes lipid and glucose metabolic disorders associated with high-fat diet consumption. Gut 2016, 65, 1871-1881. [CrossRef]

56. Loyer, X.; Paradis, V.; Hénique, C.; Vion, A.-C.; Colnot, N.; Guerin, C.L.; Devue, C.; On, S.; Scetbun, J.; Romain, M.; et al. Liver microRNA-21 is overexpressed in non-alcoholic steatohepatitis and contributes to the disease in experimental models by inhibiting PPAR $\alpha$ expression. Gut 2016, 65, 1882-1894. [CrossRef] [PubMed] 
57. Rodrigues, P.; Afonso, M.; Simão, A.; Carvalho, C.C.; Trindade, A.; Duarte, A.; Borralho, P.M.; Machado, M.V.; Cortez-Pinto, H.; Rodrigues, C.; et al. miR-21 ablation and obeticholic acid ameliorate nonalcoholic steatohepatitis in mice. Cell Death Dis. 2017, 8, e2748. [CrossRef] [PubMed]

58. Liu, M.-X.; Gao, M.; Li, C.-Z.; Yu, C.-Z.; Yan, H.; Peng, C.; Li, Y.; Li, C.-G.; Ma, Z.-L.; Zhao, Y.; et al. Dicer1/miR-29/HMGCR axis contributes to hepatic free cholesterol accumulation in mouse non-alcoholic steatohepatitis. Acta Pharmacol. Sin. 2017, 38, 660-671. [CrossRef]

59. Ding, J.; Li, M.; Wan, X.; Jin, X.; Chen, S.; Yu, C.; Li, Y. Effect of miR-34a in regulating steatosis by targeting PPAR $\alpha$ expression in nonalcoholic fatty liver disease. Sci. Rep. 2015, 5, 13729. [CrossRef]

60. Long, J.-K.; Dai, W.; Zheng, Y.-W.; Zhao, S.-P. miR-122 promotes hepatic lipogenesis via inhibiting the $L K B 1 / A M P K$ pathway by targeting Sirt1 in non-alcoholic fatty liver disease. Mol. Med. 2019, 25, 26. [CrossRef]

61. Chen, X.; Tan, X.-R.; Li, S.-J.; Zhang, X.-X. LncRNA NEAT1 promotes hepatic lipid accumulation via regulating miR-146a$5 p / R O C K 1$ in nonalcoholic fatty liver disease. Life Sci. 2019, 235, 116829. [CrossRef]

62. Huang, R.; Duan, X.; Liu, X.; Cao, H.; Wang, Y.; Fan, J.; Wang, B. Upregulation of miR-181a impairs lipid metabolism by targeting PPAR $\alpha$ expression in nonalcoholic fatty liver disease. Biochem. Biophys. Res. Commun. 2019, 508, 1252-1258. [CrossRef]

63. Liu, X.-L.; Cao, H.-X.; Wang, B.-C.; Xin, F.-Z.; Zhang, R.-N.; Zhou, D.; Yang, R.-X.; Zhao, Z.-H.; Pan, Q.; Fan, J.-G. miR-192-5p regulates lipid synthesis in non-alcoholic fatty liver disease through SCD-1. World J. Gastroenterol. 2017, 23, 8140-8151. [CrossRef]

64. Hu, Y.; Ye, H.; Shi, L.-X. MicroRNA-205 ameliorates lipid accumulation in non-alcoholic fatty liver disease through targeting NEU1. Eur. Rev. Med. Pharmacol. Sci. 2019, 23, 10072-10082. [PubMed]

65. Fernández-Tussy, P.; Fernández-Ramos, D.; Lopitz-Otsoa, F.; Simón, J.; Barbier-Torres, L.; Gomez-Santos, B.; Nuñez-Garcia, M.; Azkargorta, M.; Juan, V.G.-D.; Serrano-Macia, M.; et al. miR-873-5p targets mitochondrial GNMT-Complex II interface contributing to non-alcoholic fatty liver disease. Mol. Metab. 2019, 29, 40-54. [CrossRef] [PubMed]

66. Tsai, E.; Lee, T.-P. Diagnosis and Evaluation of Nonalcoholic Fatty Liver Disease/Nonalcoholic Steatohepatitis, Including Noninvasive Biomarkers and Transient Elastography. Clin. Liver Dis. 2018, 22, 73-92. [CrossRef] [PubMed]

67. Luo, Y.; Wadhawan, S.; Greenfield, A.; Decato, B.E.; Oseini, A.M.; Collen, R.; Shevell, D.E.; Thompson, J.; Jarai, G.; Charles, E.D.; et al. SOMAscan Proteomics Identifies Serum Biomarkers Associated with Liver Fibrosis in Patients With NASH. Hepatol. Commun. 2021, 5, 760-773. [CrossRef] [PubMed]

68. Kozumi, K.; Kodama, T.; Murai, H.; Sakane, S.; Govaere, O.; Cockell, S.; Motooka, D.; Kakita, N.; Yamada, Y.; Kondo, Y.; et al. Transcriptomics Identify Thrombospondin-2 as a Biomarker for Nonalcoholic Steatohepatitis and Advanced Liver Fibrosis. Hepatology 2021. [CrossRef] [PubMed]

69. Yoshioka, Y.; Hashimoto, E.; Yatsuji, S.; Kaneda, H.; Taniai, M.; Tokushige, K.; Shiratori, K. Nonalcoholic steatohepatitis: Cirrhosis, hepatocellular carcinoma, and burnt-out NASH. J. Gastroenterol. 2004, 39, 1215-1218. [CrossRef] [PubMed]

70. Van Der Poorten, D.; Samer, C.F.; Ramezani-Moghadam, M.; Coulter, S.; Kacevska, M.; Schrijnders, D.; Wu, L.; McLeod, D.; Bugianesi, E.; Komuta, M.; et al. Hepatic fat loss in advanced nonalcoholic steatohepatitis: Are alterations in serum adiponectin the cause? Hepatology 2012, 57, 2180-2188. [CrossRef] [PubMed]

71. Catanzaro, R.; Selvaggio, F.; Sciuto, M.; Zanoli, L.; Yazdani, A.; He, F.; Marotta, F. Triglycerides to high-density lipoprotein cholesterol ratio for diagnosing nonalcoholic fatty liver disease. Minerva Gastroenterol. 2021, 33829728. [CrossRef]

72. Fan, N.; Peng, L.; Xia, Z.; Zhang, L.; Song, Z.; Wang, Y.; Peng, Y. Triglycerides to high-density lipoprotein cholesterol ratio as a surrogate for nonalcoholic fatty liver disease: A cross-sectional study. Lipids Health Dis. 2019, 18, 1-6. [CrossRef] [PubMed]

73. Cengiz, M.; Yilmaz, G.; Ozenirler, S. Serum Biglycan as a Diagnostic Marker for Non-Alcoholic Steatohepatitis and Liver Fibrosis. Clin. Lab. 2021, 67. [CrossRef]

74. Ciftciler, R.; Ozenirler, S.; Yucel, A.A.; Cengiz, M.; Erkan, G.; Buyukdemirci, E.; Sönmez, C.; Esendaglı, G.Y. The importance of serum biglycan levels as a fibrosis marker in patients with chronic hepatitis B. J. Clin. Lab. Anal. 2016, 31, e22109. [CrossRef] [PubMed]

75. Yip, T.C.-F.; Ma, A.J.; Wong, V.W.-S.; Tse, Y.-K.; Chan, H.L.-Y.; Yuen, P.-C.; Wong, G.L.-H. Laboratory parameter-based machine learning model for excluding non-alcoholic fatty liver disease (NAFLD) in the general population. Aliment. Pharmacol. Ther. 2017, 46, 447-456. [CrossRef] [PubMed]

76. Lee, J.-H.; Kim, D.; Kim, H.J.; Lee, C.-H.; Yang, J.I.; Kim, W.; Kim, Y.J.; Yoon, J.-H.; Cho, S.-H.; Sung, M.-W.; et al. Hepatic steatosis index: A simple screening tool reflecting nonalcoholic fatty liver disease. Dig. Liver Dis. 2010, 42, 503-508. [CrossRef] [PubMed]

77. Harrison, S.A.; Oliver, D.; Arnold, H.L.; Gogia, S.; Neuschwander-Tetri, B.A. Development and validation of a simple NAFLD clinical scoring system for identifying patients without advanced disease. Gut 2008, 57, 1441-1447. [CrossRef]

78. Raszeja-Wyszomirska, J.; Szymanik, B.; Ławniczak, M.; Kajor, M.; Chwist, A.; Milkiewicz, P.; Hartleb, M. Validation of the BARD scoring system in Polish patients with nonalcoholic fatty liver disease (NAFLD). BMC Gastroenterol. 2010, 10, 67. [CrossRef]

79. Vallet-Pichard, A.; Mallet, V.; Nalpas, B.; Verkarre, V.; Nalpas, A.; Dhalluin-Venier, V.; Fontaine, H.; Pol, S. FIB-4: An inexpensive and accurate marker of fibrosis in HCV infection. Comparison with liver biopsy and fibrotest. Hepatology 2007, 46, 32-36. [CrossRef]

80. McPherson, S.; Stewart, S.F.; Henderson, E.; Burt, A.; Day, C.P. Simple non-invasive fibrosis scoring systems can reliably exclude advanced fibrosis in patients with non-alcoholic fatty liver disease. Gut 2010, 59, 1265-1269. [CrossRef] 
81. Kim, B.K.; Kim, D.Y.; Park, J.Y.; Ahn, S.H.; Chon, C.Y.; Kim, J.K.; Paik, Y.H.; Lee, K.S.; Park, Y.N.; Han, K.-H. Validation of FIB-4 and comparison with other simple noninvasive indices for predicting liver fibrosis and cirrhosis in hepatitis B virus-infected patients. Liver Int. 2010, 30, 546-553. [CrossRef] [PubMed]

82. Angulo, P.; Hui, J.M.; Marchesini, G.; Bugianesi, E.; George, J.; Farrell, G.C.; Enders, F.; Saksena, S.; Burt, A.D.; Bida, J.P.; et al. The NAFLD fibrosis score: A noninvasive system that identifies liver fibrosis in patients with NAFLD. Hepatology 2007, 45, 846-854. [CrossRef] [PubMed]

83. Bedogni, G.; Bellentani, S.; Miglioli, L.; Masutti, F.; Passalacqua, M.; Castiglione, A.; Tiribelli, C. The Fatty Liver Index: A simple and accurate predictor of hepatic steatosis in the general population. BMC Gastroenterol. 2006, 6, 33. [CrossRef]

84. Castellana, M.; Donghia, R.; Guerra, V.; Procino, F.; Lampignano, L.; Castellana, F.; Zupo, R.; Sardone, R.; De Pergola, G.; Romanelli, F.; et al. Performance of Fatty Liver Index in Identifying Non-Alcoholic Fatty Liver Disease in Population Studies. A Meta-Analysis. J. Clin. Med. 2021, 10, 1877. [CrossRef]

85. Wu, J.; Li, H.; Xu, Z.; Ran, L.; Kong, L.-Q. Population-specific cut-off points of fatty liver index for the diagnosis of hepatic steatosis. J. Hepatol. 2021. [CrossRef] [PubMed]

86. Kühn, T.; Nonnenmacher, T.; Sookthai, D.; Schübel, R.; Pacheco, D.A.Q.; Von Stackelberg, O.; Graf, M.E.; Johnson, T.; Schlett, C.; Kirsten, R.; et al. Anthropometric and blood parameters for the prediction of NAFLD among overweight and obese adults. BMC Gastroenterol. 2018, 18, 113. [CrossRef] [PubMed]

87. Ristic-Medic, D.; Kovacic, M.; Takic, M.; Arsic, A.; Petrovic, S.; Paunovic, M.; Jovicic, M.; Vucic, V. Calorie-Restricted Mediterranean and Low-Fat Diets Affect Fatty Acid Status in Individuals with Nonalcoholic Fatty Liver Disease. Nutrients 2020, 13, 15. [CrossRef] [PubMed]

88. Holmer, M.; Lindqvist, C.; Petersson, S.; Moshtaghi-Svensson, J.; Tillander, V.; Brismar, T.B.; Hagström, H.; Stål, P. Treatment of NAFLD with intermittent calorie restriction or low-carb high-fat diet-A randomised controlled trial. JHEP Rep. 2021, 3, 100256. [CrossRef] [PubMed]

89. Ghetti, F.D.F.; De Oliveira, D.G.; De Oliveira, J.M.; Ferreira, L.E.V.V.D.C.; Cesar, D.E.; Moreira, A.P.B. Effects of Dietary Intervention on Gut Microbiota and Metabolic-Nutritional Profile of Outpatients with Non-Alcoholic Steatohepatitis: A Randomized Clinical Trial. J. Gastrointest. Liver Dis. 2019, 28, 279-287. [CrossRef] [PubMed]

90. Razavi Zade, M.; Telkabadi, M.H.; Bahmani, F.; Salehi, B.; Farshbaf, S.; Asemi, Z. The effects of DASH diet on weight loss and metabolic status in adults with non-alcoholic fatty liver disease: A randomized clinical trial. Liver Int. 2016, 36, 563-571. [CrossRef]

91. Song, E.; Kim, J.A.; Roh, E.; Yu, J.H.; Kim, N.H.; Yoo, H.J.; Seo, J.A.; Kim, S.G.; Kim, N.H.; Baik, S.H.; et al. Long Working Hours and Risk of Nonalcoholic Fatty Liver Disease: Korea National Health and Nutrition Examination Survey VII. Front. Endocrinol. 2021, 12, 647459. [CrossRef] [PubMed]

92. Kobayashi, T.; Suzuki, E.; Takao, S.; Doi, H. Long working hours and metabolic syndrome among Japanese men: A cross-sectional study. BMC Public Health 2012, 12, 395. [CrossRef] [PubMed]

93. Virtanen, M.; Heikkila, K.; Jokela, M.; Ferrie, J.E.; Batty, G.; Vahtera, J.; Kivimaki, M. Long Working Hours and Coronary Heart Disease: A Systematic Review and Meta-Analysis. Am. J. Epidemiol. 2012, 176, 586-596. [CrossRef] [PubMed]

94. Kivimaki, M.; Jokela, M.; Nyberg, S.T.; Singh-Manoux, A.; Fransson, E.I.; Alfredsson, L.; Bjorner, J.B.; Borritz, M.; Burr, H.; Casini, A.; et al. Long working hours and risk of coronary heart disease and stroke: A systematic review and meta-analysis of published and unpublished data for 603838 individuals. Lancet 2015, 386, 1739-1746. [CrossRef]

95. McCambridge, J.; Witton, J.; Elbourne, D.R. Systematic review of the Hawthorne effect: New concepts are needed to study research participation effects. J. Clin. Epidemiol. 2014, 67, 267-277. [CrossRef]

96. Glass, O.; Filozof, C.; Noureddin, M.; Berner-Hansen, M.; Schabel, E.; Omokaro, S.O.; Schattenberg, J.M.; Barradas, K.; Miller, V.; Francque, S.; et al. Standardisation of diet and exercise in clinical trials of NAFLD-NASH: Recommendations from the Liver Forum. J. Hepatol. 2020, 73, 680-693. [CrossRef] [PubMed]

97. Miura, I.; Komine, S.; Okada, K.; Wada, S.; Warabi, E.; Uchida, F.; Oh, S.; Suzuki, H.; Mizokami, Y.; Shoda, J. Prevention of non-alcoholic steatohepatitis by long-term exercise via the induction of phenotypic changes in Kupffer cells of hyperphagic obese mice. Physiol. Rep. 2021, 9, e14859. [CrossRef] [PubMed]

98. Kasper, P.; Breuer, S.; Hoffmann, T.; Vohlen, C.; Janoschek, R.; Schmitz, L.; Appel, S.; Fink, G.; Hünseler, C.; Quaas, A.; et al. Maternal Exercise Mediates Hepatic Metabolic Programming via Activation of AMPK-PGC1 $\alpha$ Axis in the Offspring of Obese Mothers. Cells 2021, 10, 1247. [CrossRef]

99. Battista, F.; Ermolao, A.; van Baak, M.A.; Beaulieu, K.; Blundell, J.E.; Busetto, L.; Carraça, E.V.; Encantado, J.; Dicker, D.; FarpourLambert, N.; et al. Effect of exercise on cardiometabolic health of adults with overweight or obesity: Focus on blood pressure, insulin resistance, and intrahepatic fat-A systematic review and meta-analysis. Obes. Rev. 2021, 22, e13269. [CrossRef]

100. Cornejo-Pareja, I.; Clemente-Postigo, M.; Tinahones, F.J. Metabolic and Endocrine Consequences of Bariatric Surgery. Front. Endocrinol. 2019, 10, 626. [CrossRef]

101. Skuratovskaia, D.; Vulf, M.; Chasovskikh, N.; Komar, A.; Kirienkova, E.; Shunkin, E.; Zatolokin, P.; Litvinova, L. The Links of Ghrelin to Incretins, Insulin, Glucagon, and Leptin after Bariatric Surgery. Front. Genet. 2021, 12, 612501. [CrossRef] [PubMed]

102. Syn, N.L.; Cummings, D.E.; Wang, L.Z.; Lin, D.J.; Zhao, J.J.; Loh, M.; Koh, Z.J.; Chew, C.A.; Loo, Y.E.; Tai, B.C.; et al. Association of metabolic-bariatric surgery with long-term survival in adults with and without diabetes: A one-stage meta-analysis of matched cohort and prospective controlled studies with 174,772 participants. Lancet 2021, 397, 1830-1841. [CrossRef] 
103. Cherla, D.V.; Rodriguez, N.A.; Vangoitsenhoven, R.; Singh, T.; Mehta, N.; McCullough, A.J.; Brethauer, S.A.; Schauer, P.R.; Aminian, A. Impact of sleeve gastrectomy and Roux-en-Y gastric bypass on biopsy-proven non-alcoholic fatty liver disease. Surg. Endosc. 2019, 34, 2266-2272. [CrossRef]

104. Kalinowski, P.; Paluszkiewicz, R.; Ziarkiewicz-Wróblewska, B.; Wróblewski, T.; Remiszewski, P.; Grodzicki, M.; Krawczyk, M. Liver Function in Patients with Nonalcoholic Fatty Liver Disease Randomized to Roux-en-Y Gastric Bypass versus Sleeve Gastrectomy. Ann. Surg. 2017, 266, 738-745. [CrossRef]

105. Wölnerhanssen, B.K.; Peterli, R.; Hurme, S.; Bueter, M.; Helmiö, M.; Juuti, A.; Meyer-Gerspach, A.C.; Slawik, M.; PeromaaHaavisto, P.; Nuutila, P.; et al. Laparoscopic Roux-en-Y gastric bypass versus laparoscopic sleeve gastrectomy: 5-year outcomes of merged data from two randomized clinical trials (SLEEVEPASS and SM-BOSS). BJS 2021, 108, 49-57. [CrossRef]

106. Pajecki, D.; Dantas, A.C.B.; Tustumi, F.; Kanaji, A.L.; de Cleva, R.; Santo, M.A. Sleeve Gastrectomy Versus Roux-en-Y Gastric Bypass in the Elderly: 1-Year Preliminary Outcomes in a Randomized Trial (BASE Trial). Obes. Surg. 2021, 31, $2359-2363$. [CrossRef]

107. Iwaki, M.; Kessoku, T.; Ozaki, A.; Kasai, Y.; Kobayashi, T.; Nogami, A.; Honda, Y.; Ogawa, Y.; Imajo, K.; Yoneda, M.; et al. Gut microbiota composition associated with hepatic fibrosis in non-obese patients with non-alcoholic fatty liver disease. J. Gastroenterol. Hepatol. 2021. [CrossRef]

108. Lee, G.; You, H.J.; Bajaj, J.S.; Joo, S.K.; Yu, J.; Park, S.; Kang, H.; Park, J.H.; Kim, J.H.; Lee, D.H.; et al. Distinct signatures of gut microbiome and metabolites associated with significant fibrosis in non-obese NAFLD. Nat. Commun. 2020, 11, 4982. [CrossRef]

109. Zhang, C.; Yang, M.; Ericsson, A.C. The Potential Gut Microbiota-Mediated Treatment Options for Liver Cancer. Front. Oncol. 2020, 10, 524205. [CrossRef] [PubMed]

110. Pan, X.; Wen, S.W.; Kaminga, A.C.; Liu, A. Gut metabolites and inflammation factors in non-alcoholic fatty liver disease: A systematic review and meta-analysis. Sci. Rep. 2020, 10, 1-11. [CrossRef] [PubMed]

111. Craven, L.; Rahman, A.; Parvathy, S.N.; Beaton, M.; Silverman, J.; Qumosani, K.; Hramiak, I.; Hegele, R.; Joy, T.; Meddings, J.; et al. Allogenic Fecal Microbiota Transplantation in Patients with Nonalcoholic Fatty Liver Disease Improves Abnormal Small Intestinal Permeability: A Randomized Control Trial. Am. J. Gastroenterol. 2020, 115, 1055-1065. [CrossRef] [PubMed]

112. Scorletti, E.; Afolabi, P.R.; Miles, E.A.; Smith, D.E.; Almehmadi, A.; AlShathry, A.; Childs, C.E.; Del Fabbro, S.; Bilson, J.; Moyses, H.E.; et al. Synbiotics Alter Fecal Microbiomes, But Not Liver Fat or Fibrosis, in a Randomized Trial of Patients with Nonalcoholic Fatty Liver Disease. Gastroenterology 2020, 158, 1597-1610.e7. [CrossRef] [PubMed]

113. Campisciano, G.; Palmisano, S.; Cason, C.; Giuricin, M.; Silvestri, M.; Guerra, M.; Macor, D.; De Manzini, N.; Crocé, L.; Comar, M. Gut microbiota characterisation in obese patients before and after bariatric surgery. Benef. Microbes 2018, 9, 367-373. [CrossRef]

114. Li, J.V.; Ashrafian, H.; Sarafian, M.; Homola, D.; Rushton, L.; Barker, G.; Cabrera, P.M.; Lewis, M.R.; Darzi, A.; Lin, E.; et al. Roux-en-Y gastric bypass-induced bacterial perturbation contributes to altered host-bacterial co-metabolic phenotype. Microbiome 2021, 9, 1-15. [CrossRef]

115. Loosen, S.H.; Demir, M.; Kunstein, A.; Jördens, M.; Qvarskhava, N.; Luedde, M.; Luedde, T.; Roderburg, C.; Kostev, K. Variables associated with increased incidence of non-alcoholic fatty liver disease (NAFLD) in patients with type 2 diabetes. BMJ Open Diabetes Res. Care 2021, 9, e002243. [CrossRef] [PubMed]

116. Ganjooei, N.A.; Jamialahmadi, T.; Nematy, M.; Jangjoo, A.; Goshayeshi, L.; Khadem-Rezaiyan, M.; Reiner, Ž.; Alidadi, M.; Markin, A.M.; Sahebkar, A. The Role of Lipid Profile as an Independent Predictor of Non-alcoholic Steatosis and Steatohepatitis in Morbidly Obese Patients. Front. Cardiovasc. Med. 2021, 8, 682352. [CrossRef]

117. Kumar, D.P.; Caffrey, R.; Marioneaux, J.; Santhekadur, P.K.; Bhat, M.; Alonso, C.; Koduru, S.V.; Philip, B.; Jain, M.R.; Giri, S.R.; et al. The PPAR $\alpha / \gamma$ Agonist Saroglitazar Improves Insulin Resistance and Steatohepatitis in a Diet Induced Animal Model of Nonalcoholic Fatty Liver Disease. Sci. Rep. 2020, 10, 1-14. [CrossRef]

118. Gawrieh, S.; Noureddin, M.; Loo, N.; Mohseni, R.; Awasty, V.; Cusi, K.; Kowdley, K.V.; Lai, M.; Schiff, E.; Parmar, D.; et al. Saroglitazar, a PPAR $-\alpha / \gamma$ Agonist, for Treatment of Nonalcoholic Fatty Liver Disease: A Randomized Controlled Double-Blind Phase 2 Trial. Hepatology 2021. [CrossRef]

119. Schmitt, J.; Kong, B.; Stieger, B.; Tschopp, O.; Schultze, S.M.; Rau, M.; Weber, A.; Mullhaupt, B.; Guo, G.L.; Geier, A. Protective effects of farnesoid $X$ receptor $(F X R)$ on hepatic lipid accumulation are mediated by hepatic $F X R$ and independent of intestinal FGF15 signal. Liver Int. 2015, 35, 1133-1144. [CrossRef]

120. Liu, M.; Zhang, G.; Wu, S.; Song, M.; Wang, J.; Cai, W.; Mi, S.; Liu, C. Schaftoside alleviates HFD-induced hepatic lipid accumulation in mice via upregulating farnesoid $X$ receptor. J. Ethnopharmacol. 2020, 255, 112776. [CrossRef] [PubMed]

121. Amano, Y.; Shimada, M.; Miura, S.; Adachi, R.; Tozawa, R. Effects of a farnesoid X receptor antagonist on hepatic lipid metabolism in primates. Eur. J. Pharmacol. 2014, 723, 108-115. [CrossRef]

122. Ma, K.; Saha, P.K.; Chan, L.; Moore, D.D. Farnesoid X receptor is essential for normal glucose homeostasis. J. Clin. Investig. 2006, 116, 1102-1109. [CrossRef]

123. Patel, K.; Harrison, S.A.; Elkashab, M.; Trotter, J.F.; Herring, R.; Rojter, S.; Kayali, Z.; Wong, V.W.-S.; Greenbloom, S.; Jayakumar, S.; et al. Cilofexor, a Nonsteroidal FXR Agonist, in Non-Cirrhotic Patients with Nonalcoholic Steatohepatitis: A Phase 2 Randomized Controlled Trial. Hepatology 2020, 72, 58-71. [CrossRef]

124. Zhang, E.; Zhao, Y.; Hu, H. Impact of Sodium Glucose Cotransporter 2 Inhibitors on Nonalcoholic Fatty Liver Disease Complicated by Diabetes Mellitus. Hepatol. Commun. 2021, 5, 736-748. [CrossRef] [PubMed] 
125. Wong, C.; Lee, M.H.; Yaow, C.Y.L.; Chin, Y.H.; Goh, X.L.; Ng, C.H.; Lim, A.Y.L.; Muthiah, M.D.; Khoo, C.M. Glucagon-Like Peptide-1 Receptor Agonists for Non-Alcoholic Fatty Liver Disease in Type 2 Diabetes: A Meta-Analysis. Front. Endocrinol. 2021, 12, 609110. [CrossRef] [PubMed]

126. Sivitz, W.I.; Phillips, L.S.; Wexler, D.J.; Fortmann, S.P.; Camp, A.W.; Tiktin, M.; Perez, M.; Craig, J.; Hollander, P.A.; Cherrington, A.; et al. Optimization of Metformin in the GRADE Cohort: Effect on Glycemia and Body Weight. Diabetes Care 2020, 43, 940-947. [CrossRef] [PubMed]

127. Gillani, S.W.; Ghayedi, N.; Roosta, P.; Seddigh, P.; Nasiri, O. Effect of Metformin on Lipid Profiles of Type 2 Diabetes Mellitus: A Metaanalysis of Randomized Controlled Trials. J. Pharm. Bioallied Sci. 2021, 13, 76-82. [CrossRef] [PubMed]

128. Lamos, E.M.; Kristan, M.; Siamashvili, M.; Davis, S.N. Effects of anti-diabetic treatments in type 2 diabetes and fatty liver disease. Expert Rev. Clin. Pharmacol. 2021, 10, 1-16. [CrossRef] [PubMed]

129. Amanullah, I.; Khan, Y.H.; Anwar, I.; Gulzar, A.; Mallhi, T.H.; Raja, A.A. Effect of vitamin E in non-alcoholic fatty liver disease: A systematic review and meta-analysis of randomised controlled trials. Postgrad. Med. J. 2019, 95, 601-611. [CrossRef]

130. Sebastiani, G.; Saeed, S.; Lebouche, B.; De Pokomandy, A.; Szabo, J.; Haraoui, L.-P.; Routy, J.-P.; Wong, P.; Deschenes, M.; Ghali, P.; et al. Vitamin $\mathrm{E}$ is an effective treatment for nonalcoholic steatohepatitis in HIV mono-infected patients. AIDS 2020, 34, 237-244. [CrossRef] [PubMed]

131. Abenavoli, L.; Larussa, T.; Corea, A.; Procopio, A.; Boccuto, L.; Dallio, M.; Federico, A.; Luzza, F. Dietary Polyphenolsand Non-Alcoholic Fatty Liver Disease. Nutrients 2021, 13, 494. [CrossRef] [PubMed]

132. Salehi-Sahlabadi, A.; Teymoori, F.; Jabbari, M.; Momeni, A.; Mokari-Yamchi, A.; Sohouli, M.; Hekmatdoost, A. Dietary polyphenols and the odds of non-alcoholic fatty liver disease: A case-control study. Clin. Nutr. ESPEN 2021, 41, 429-435. [CrossRef] [PubMed]

133. Fujinaga, Y.; Kawaratani, H.; Kaya, D.; Tsuji, Y.; Ozutsumi, T.; Furukawa, M.; Kitagawa, K.; Sato, S.; Nishimura, N.; Sawada, Y.; et al. Effective Combination Therapy of Angiotensin-II Receptor Blocker and Rifaximin for Hepatic Fibrosis in Rat Model of Nonalcoholic Steatohepatitis. Int. J. Mol. Sci. 2020, 21, 5589. [CrossRef]

134. Gangarapu, V.; Ince, A.T.; Baysal, B.; Kayar, Y.; Kılıç, U.; Gök, Ö.; Uysal, Ö.; Şenturk, H. Efficacy of rifaximin on circulating endotoxins and cytokines in patients with nonalcoholic fatty liver disease. Eur. J. Gastroenterol. Hepatol. 2015, 27, 840-845. [CrossRef] [PubMed]

135. Loomba, R.; Lawitz, E.; Mantry, P.S.; Jayakumar, S.; Caldwell, S.H.; Arnold, H.; Diehl, A.M.; Djedjos, C.S.; Han, L.; Myers, R.P.; et al. The ASK1 inhibitor selonsertib in patients with nonalcoholic steatohepatitis: A randomized, phase 2 trial. Hepatology 2018, 67, 549-559. [CrossRef]

136. Harrison, S.A.; Wong, V.; Okanoue, T.; Bzowej, N.; Vuppalanchi, R.; Younes, Z.; Kohli, A.; Sarin, S.; Caldwell, S.H.; Alkhouri, N.; et al. Selonsertib for patients with bridging fibrosis or compensated cirrhosis due to NASH: Results from randomized phase III STELLAR trials. J. Hepatol. 2020, 73, 26-39. [CrossRef]

137. Loomba, R.; Noureddin, M.; Kowdley, K.V.; Kohli, A.; Sheikh, A.; Neff, G.; Bhandari, B.R.; Gunn, N.; Caldwell, S.H.; Goodman, Z.; et al. Combination Therapies Including Cilofexor and Firsocostat for Bridging Fibrosis and Cirrhosis Attributable to NASH. Hepatology 2021, 73, 625-643. [CrossRef] [PubMed]

138. Geng, Y.; Villanueva, A.H.; Oun, A.; Buist-Homan, M.; Blokzijl, H.; Faber, K.N.; Dolga, A.; Moshage, H. Protective effect of metformin against palmitate-induced hepatic cell death. Biochim. Biophys. Acta (BBA) Mol. Basis Dis. 2020, $1866,165621$. [CrossRef]

139. Wells, R.G. Cellular Sources of Extracellular Matrix in Hepatic Fibrosis. Clin. Liver Dis. 2008, 12, 759-768. [CrossRef]

140. Kisseleva, T. The origin of fibrogenic myofibroblasts in fibrotic liver. Hepatology 2017, 65, 1039-1043. [CrossRef]

141. Liu, B.; Deng, X.; Jiang, Q.; Li, G.; Zhang, J.; Zhang, N.; Xin, S.; Xu, K. Scoparone alleviates inflammation, apoptosis and fibrosis of non-alcoholic steatohepatitis by suppressing the $T L R 4 / N F-\kappa B$ signaling pathway in mice. Int. Immunopharmacol. $2019,75,105797$. [CrossRef] [PubMed]

142. Yang, M.; Zhang, C.-Y. G protein-coupled receptors as potential targets for nonalcoholic fatty liver disease treatment. World J. Gastroenterol. 2021, 27, 677-691. [CrossRef] [PubMed]

143. Chen, C.-Y.; Li, Y.; Zeng, N.; He, L.; Zhang, X.; Tu, T.; Tang, Q.; Alba, M.; Mir, S.; Stiles, E.X.; et al. Inhibition of Estrogen-Related Receptor $\alpha$ Blocks Liver Steatosis and Steatohepatitis and Attenuates Triglyceride Biosynthesis. Am. J. Pathol. 2021, 191, 1240-1254. [CrossRef]

144. Yang, M.; Zhang, C. The role of bone morphogenetic proteins in liver fibrosis. Gastroenterol. Hepatol. Open Access 2021, 12, 17-20. [CrossRef]

145. Sun, N.; Shen, C.; Zhang, L.; Wu, X.; Yu, Y.; Yang, X.; Yang, C.; Zhong, C.; Gao, Z.; Miao, W.; et al. Hepatic Krüppel-like factor 16 (KLF16) targets PPAR $\alpha$ to improve steatohepatitis and insulin resistance. Gut 2020, 10, 1136. [CrossRef]

146. Newsome, P.N.; Buchholtz, K.; Cusi, K.; Linder, M.; Okanoue, T.; Ratziu, V.; Sanyal, A.J.; Sejling, A.-S.; Harrison, S.A. A Placebo-Controlled Trial of Subcutaneous Semaglutide in Nonalcoholic Steatohepatitis. N. Engl. J. Med. 2021, 384, 1113-1124. [CrossRef]

147. Harrison, S.A.; Alkhouri, N.; Davison, B.A.; Sanyal, A.; Edwards, C.; Colca, J.R.; Lee, B.H.; Loomba, R.; Cusi, K.; Kolterman, O.; et al. Insulin sensitizer MSDC-0602K in non-alcoholic steatohepatitis: A randomized, double-blind, placebo-controlled phase IIb study. J. Hepatol. 2020, 72, 613-626. [CrossRef] [PubMed] 
148. Palmer, M.; Jennings, L.; Silberg, D.G.; Bliss, C.; Martin, P. A randomised, double-blind, placebo-controlled phase 1 study of the safety, tolerability and pharmacodynamics of volixibat in overweight and obese but otherwise healthy adults: Implications for treatment of non-alcoholic steatohepatitis. BMC Pharmacol. Toxicol. 2018, 19, 10. [CrossRef]

149. Trauner, M.; Gulamhusein, A.; Hameed, B.; Caldwell, S.; Shiffman, M.L.; Landis, C.; Eksteen, B.; Agarwal, K.; Muir, A.; Rushbrook, S.; et al. The Nonsteroidal Farnesoid X Receptor Agonist Cilofexor (GS-9674) Improves Markers of Cholestasis and Liver Injury in Patients with Primary Sclerosing Cholangitis. Hepatology 2019, 70, 788-801. [CrossRef]

150. Hoofnagle, J.H.; Van Natta, M.L.; Kleiner, D.; Clark, J.M.; Kowdley, K.V.; Loomba, R.; Neuschwander-Tetri, B.A.; Sanyal, A.J.; Tonascia, J.; the Non-alcoholic Steatohepatitis Clinical Research Network (NASH CRN). Vitamin E and changes in serum alanine aminotransferase levels in patients with non-alcoholic steatohepatitis. Aliment. Pharmacol. Ther. 2013, 38, 134-143. [CrossRef]

151. Podszun, M.C.; Alawad, A.S.; Lingala, S.; Morris, N.; Huang, W.-C.A.; Yang, S.; Schoenfeld, M.; Rolt, A.; Ouwerkerk, R.; Valdez, K.; et al. Vitamin E treatment in NAFLD patients demonstrates that oxidative stress drives steatosis through upregulation of de-novo lipogenesis. Redox Biol. 2020, 37, 101710. [CrossRef] [PubMed]

152. Lawitz, E.J.; Coste, A.; Poordad, F.; Alkhouri, N.; Loo, N.; McColgan, B.J.; Tarrant, J.M.; Nguyen, T.; Han, L.; Chung, C.; et al. Acetyl-CoA Carboxylase Inhibitor GS-0976 for 12 Weeks Reduces Hepatic De Novo Lipogenesis and Steatosis in Patients With Nonalcoholic Steatohepatitis. Clin. Gastroenterol. Hepatol. 2018, 16, 1983-1991.e3. [CrossRef] [PubMed]

153. Loomba, R.; Kayali, Z.; Noureddin, M.; Ruane, P.; Lawitz, E.J.; Bennett, M.; Wang, L.; Harting, E.; Tarrant, J.M.; McColgan, B.J.; et al. GS-0976 Reduces Hepatic Steatosis and Fibrosis Markers in Patients with Nonalcoholic Fatty Liver Disease. Gastroenterology 2018, 155, 1463-1473.e6. [CrossRef]

154. Sanyal, A.; Charles, E.D.; Neuschwander-Tetri, B.A.; Loomba, R.; Harrison, S.A.; Abdelmalek, M.; Lawitz, E.J.; HalegouaDeMarzio, D.; Kundu, S.; Noviello, S.; et al. Pegbelfermin (BMS-986036), a PEGylated fibroblast growth factor 21 analogue, in patients with non-alcoholic steatohepatitis: A randomised, double-blind, placebo-controlled, phase 2a trial. Lancet 2018, 392, 2705-2717. [CrossRef]

155. Mudaliar, S.; Henry, R.R.; Sanyal, A.J.; Morrow, L.; Marschall, H.-U.; Kipnes, M.; Adorini, L.; Sciacca, C.I.; Clopton, P.; Castelloe, E.; et al. Efficacy and Safety of the Farnesoid X Receptor Agonist Obeticholic Acid in Patients With Type 2 Diabetes and Nonalcoholic Fatty Liver Disease. Gastroenterology 2013, 145, 574-582.e1. [CrossRef] [PubMed]

156. Vos, M.B.; Jin, R.; Konomi, J.V.; Cleeton, R.; Cruz, J.; Karpen, S.; Rodriguez, D.S.; Frediani, J.K.; McCracken, C.; Welsh, J. A randomized, controlled, crossover pilot study of losartan for pediatric nonalcoholic fatty liver disease. Pilot Feasibility Stud. 2018, 4, 109. [CrossRef]

157. Navarro, V.J.; Belle, S.H.; D'Amato, M.; Adfhal, N.; Brunt, E.M.; Fried, M.W.; Reddy, K.R.; Wahed, A.S.; Harrison, S. Silymarin in NASH and C Hepatitis (SyNCH) Study Group Silymarin in non-cirrhotics with non-alcoholic steatohepatitis: A randomized, double-blind, placebo controlled trial. PLoS ONE 2019, 14, e0221683. [CrossRef]

158. Loomba, R.; Lutchman, G.; Kleiner, D.; Ricks, M.; Feld, J.J.; Borg, B.B.; Modi, A.; Nagabhyru, P.; Sumner, A.E.; Liang, T.J.; et al. Clinical trial: Pilot study of metformin for the treatment of non-alcoholic steatohepatitis. Aliment. Pharmacol. Ther. 2008, 29, 172-182. [CrossRef]

159. Ratziu, V.; Sanyal, A.; Harrison, S.A.; Wong, V.W.; Francque, S.; Goodman, Z.; Aithal, G.; Kowdley, K.V.; Seyedkazemi, S.; Fischer, L.; et al. Cenicriviroc Treatment for Adults with Nonalcoholic Steatohepatitis and Fibrosis: Final Analysis of the Phase 2b CENTAUR Study. Hepatology 2020, 72, 892-905. [CrossRef]

160. VanWagner, L.; Koppe, S.W.; Brunt, E.M.; Gottstein, J.; Gardikiotes, K.; Green, R.M.; Rinella, M.E. Pentoxifylline for the treatment of non-alcoholic steatohepatitis: A randomized controlled trial. Ann. Hepatol. 2011, 10, 277-286. [CrossRef]

161. Schwimmer, J.; Ugalde-Nicalo, P.; Welsh, J.A.; Angeles, J.E.; Cordero, M.; Harlow, K.E.; Alazraki, A.; Durelle, J.; Knight-Scott, J.; Newton, K.P.; et al. Effect of a Low Free Sugar Diet vs Usual Diet on Nonalcoholic Fatty Liver Disease in Adolescent Boys. JAMA 2019, 321, 256-265. [CrossRef] [PubMed]

162. Shiffman, M.; Freilich, B.; Vuppalanchi, R.; Watt, K.; Chan, J.L.; Spada, A.; Hagerty, D.T.; Schiff, E. Randomised clinical trial: Emricasan versus placebo significantly decreases ALT and caspase 3/7 activation in subjects with non-alcoholic fatty liver disease. Aliment. Pharmacol. Ther. 2018, 49, 64-73. [CrossRef] [PubMed] 